\title{
VIII. Taşnak Kongresinin Perde Arkası ya da Taşnakların I. Dünya Savaşı Öncesi Müttefik Arayışı
}

\author{
Kemal Çiçek*
}

The Dashnaktsutiun's Search for an Ally on the Eve of the First World War

Abstract $\square$ This article focuses on the rather controversial 8th World Congress of the Armenian Revolutionary Federation (ARF), held in Erzurum in August 1914. Historians are divided on the outcome of this very important congress. Historians who support the genocide thesis argue that representatives of the ruling Committee of Union and Progress were present in Erzurum during the Congress and proposed to the ARF (the leading Armenian party in both the Ottoman and the Russian Empire) to incite a rebellion against the Tsarist regime in return for an autonomous Armenia in three Ottoman vilayets/provinces. However, historians who do not agree with the genocide thesis categorically deny either a meeting between the Ottoman representatives and ARF or any proposal including autonomy. In this article, the author reviews and evaluates all available archival sources, as well as the memories of the attendees and secondary sources and draws several important conclusions. a). ARF and some Ottoman officials seem to have had negotiations in Erzurum aimed at facilitating some cooperation between Tashnak Armenians on both sides of the border and the Ottoman government in order to open a new front against Russia. b). That the Ottoman officials were fully authorized by the Ottoman government for formal talks with the ARF delegation is rather questionable; yet there is little doubt that a form of autonomy was among the promises made to the ARF delegation. c). ARF claims that the Erzurum Congress had secured the loyalty of the Armenians to the Ottoman Empire should be questioned as the ARF had decided to form and arm the so called Armenian voluntary units long before the congress commenced and the Ottoman Empire entered WWI.

Keywords: Ottoman Empire, Eighth Congress of the ARF, Committee of Union and Progress, Armenian Question, Armenian Revolutionary Federation.

* Yeni Türkiye Stratejik Araştırma Merkezi, Gölbaşı-Ankara. 


\section{Giriş $^{1}$}

VIII. Taşnak Partisi Kongresi 25 Temmuz 17 Ağustos 1914 tarihleri arasında Erzurum'da yapıldı. ${ }^{2}$ Bu kongre toplandığı sırada Avrupa'da I. Dünya Savaşı patlak vermiş, ancak Osmanlı Devleti henüz savaşa katılmamıştı. Bilindiği gibi Osmanlı Devleti Almanya ile 2 Ağustos 1914 tarihinde gizli bir ittifak antlaşması imzalamış ve aynı gün seferberlik ilan etmişti. ${ }^{3}$ Osmanlı Devleti'nin savaşa katılmasına bütün taraf devletler kesin gözüyle bakıyordu. Ayrıca beklentiler, Osmanlı Devleti'nin büyük bir ihtimalle Almanya ve müttefikleri saflarında savaşa katılacağı yönündeydi. Bununla birlite Aksakal'ın tespitlerine göre, Osmanlı devleti Almanya ile İttifak anlaşması yaptıktan sonra da itilaf devletleriyle anlaşmaya çalışı, Almanları oyaladı ve Almanya'nın baskılarına rağmen derhal savaşa

1 Bu makalede tartışılan bazı sorular daha önce yayınlanan şu makalede özet ve kısmi olarak ele alınmıştır. Ancak kurgu, kaynak ve tartışma tamamen farklıdır: Kemal Çiçek, "VIII. Taşnak Kongresi: Ermenilerin Karar Anı”, I. Uluslararası Türk-Ermeni İlişkileri ve Büyük Güçler Sempozyumu (2-4 Mayıs 2012-Erzurum/Türkiye) (Erzurum: Atatürk Üniversitesi Türk-Ermeni İlişkileri Araştırma merkezi Yayınları, 2014), s. 63-72.

2 Literatürde kongre tarihi hakkında çok farklı görüşler mevcuttur. Örneğin Hratch Dasnabedian kongrenin “Temmuz ortalarında” başlayıp "iki hafta”" sürdüğünü belirtmektedir. Ermeni kaynaklarında bile açıklık söz konusu değildir. Ancak yapmış olduğumuz araştırmalar neticesinde kongrenin Temmuz sonlarında başladığını ve Ağustos ortalarında bittiğini tespit ettik. Yine de bir kesinlik söz konusu değildir. Taşnak arşivlerine dayalı araştırma yapan Kaligian da kesin bir tarih ortaya koyamamıştır. Bkz. Mesrob Dikran Kaligian, Armenian Organization and Ideology under Ottoman Rule: 1908-1914, (London: New Brunswick, N. J: Transaction Publishers, 2011), s. 238. Kaligian kitabının ilk baskısında Ağustos son baskısında ise Temmuz kaydını düşmüştür. H. Dasnabedian bu tarihi verir. Hratch Dasnabedian, The History of the Armenian Revolutionary Federation Dashnaktsutiun (1890-1924), (Milan: Oemme Edizioni, 1989), s. 107. Bu karışıklığında sebebi kullanılan takvimler arasındaki fark olup, Rusyanın kullandığı Jülyen takvimi de miladi takvimden 13 gün geridedir. Bu farklılık gözden kaçırılmamalıdır. Rusya arşiv kaynaklarına dayalı yeni kaynaklar ortayan koyan Onur Önol da Taşnak Partisi kongre zabıtlarına dayanarak Temmuz sonunu işaret eder. Onur Önol, "The Eight World Congress of the Dashnaktsutyun and Its Aftermath", War and Collapse, ed. Hakan Yavuz and Feroz Ahmad, (Salk Lake City: Utah University Press, 2016), s. 781.

3 Antlaşmanın metni için bkz. Veli Yılmaz, "I inci Dünya Harbi ve 2 Ağustos 1914 Tarihli Türk Alman İttifak Antlaşması", Ankara Üniversitesi Türk İnkılâp Taribi Enstitüsü Atatürk Yolu Dergisi, 11 (1993), s. 121-31. Antlaşmanın değerlendirmeleri için bkz. H. S. W. Corrigan, "German-Turkish Relations and the Outbreak of War in 1914: A Re-assessment", Past \& Present, 36 (1967), s. 144-152; Ulrich Trumpener, "German Military Aid to Turkey in 1914: An Historical Re-evaluation”, The Journal of Modern History, 32/2 (1960), s. 145-149. 
girmemek için elinden geleni yaptı. ${ }^{4}$ İşte bu beklenti ve fiili vaziyet, Ermeniler için çok zor bir durum yaratmaktaydı. Çünkü Ermenilerin bir kısmı Rusya topraklarında, önemli bir kısmı da Osmanlı Devleti sınırları içerisinde yaşıyordu. Rusya ve Osmanlı Devleti karşı bloklarda yer alıyordu. Bu durumda Osmanlı sınırları dâhilinde yaşayan, ancak Rusya Ermenileri ile çok sıkı bir işbirliği içerisinde olan Osmanlı vatandaşı Ermeniler, Osmanlı Devleti Rusya ile savaşa girerse ne yapacaklardı? Osmanlı Ermenileri tam bir ikilem içerisindeydi. Osmanlı Devleti'ne sadık kalırlarsa, artık orduya da çağrıldıklarından kendi soydaşları ile savaşmak zorunda kalacaklardı. Böylelikle ya Rusya'da yaşayan soydaşlarına ya da Rusya ile beraber hareket ederlerse de kendi devletlerine ihanet etmiş olacaklardı. $\mathrm{Ne}$ var ki, her koşulda bir karar vermek zorundaydılar. İşte tam bu karar arifesinde Taşnak Partisinin 1914 yılı Temmuz sonlarında Erzurum'da toplanacak VIII. Olağan Kongresi büyük bir önem kazandı.

Planlandığı gibi kongre toplandı ve sıcak gündem maddeleri sebebiyle olsa gerek kongreye çok geniş bir katılım oldu. Kongreye Eçmiyazin, Moskova, Tiflis, Tahran, Tebriz, Amerika, Mısır, Avrupa, Rusya ve Türkiye'nin çeşitli yerlerinden otuz üye ve gözlemci katıldı. Dünyanın dört bir tarafından kongreye katılan Taşnaklar ve gözlemciler, beklendiği gibi, 8 Şubat 1914 tarihinde imzalanan Yeniköy İtilafnamesi ve Ermenilerin yaşadığı bölgelerde reform projesi ile Osmanlı Devleti savaşa katıldığı takdirde nasıl bir yol haritası izleneceğine dair maddeleri kongrenin öncelikli gündem maddeleri olarak belirlediler ve bu konuda günlerce tartıştılar. Kongre sonunda Dikran Kaligian'ın tespitlerine göre hayati öneme sahip konular hakkında karar alınamadı, ama yine Osmanlı Devleti’ni ilgilendiren bir sonuç bildirgesi açıkland1. ${ }^{5}$

Bu bildirgede, İttihat ve Terakki Partisinin kısır ve ayrımcı politikaları yüzünden gayrimüslimlerin idari, ekonomik ve eğitim bakımından durumlarının kötüleştiği ve Ermenilerin yasal ve yasadışı yollarla baskı altına alındığı belirtiliyordu. Ayrıca hükümetin, reform programının uygulanmasını bilinçli olarak engellemeye çalıştığı da vurgulanmaktaydı. Bu yüzden Taşnak Partisi, İttihat ve Terakki'ye karşı eleştirilerini güçlü bir şekilde sürdürmeye ve bu partinin fanatik ve demokrasiye aykııı politikalarına karşı tarafsız ve tavizsiz bir şekilde muhalefet etmeye karar vermişti. Bununla birlikte Taşnak Partisi, programına uygun olan

4 Mustafa Aksakal, The Ottoman Road to War in 1914: The Ottoman Empire and the First World War, (New York: Cambridge University Press, 2008), s. 112-118.

5 Kongre gündemi ve tartışmalar için bkz. Kaligian, Armenian Organization, s. 219-224. 
konularda ve devlet meselelerinde işbirliğini de ihmal etmeyecekti. ${ }^{6}$ Bu tespiti yapmakla birlikte, bu dönemde Osmanlı Ermenilerinin büyük bir kısmının artık Rusya'yı kurtarıcı olarak görme eğiliminde olduğu yönünde görüşlere katılmamak mümkün değildir. ${ }^{7}$

Kamuoyuna açıklanan bu sonuç bildirgesinin metni konusunda bir tereddüt bulunmamakla beraber gerek kongrede alınan kararlar, gerekse de toplantı sırasında veya sonrasında Osmanlı Devleti ile Taşnak Partisi arasında yaşananlar hakkında derin bir görüş ayrılığı bulunmaktadır. Sonraki yıllarda Osmanlı yetkilileri daha sonra da tarihçiler açılanan kararların gerçekleri yansıtmadığını, kongrede gizli kararlar alındığını öne sürdüler. Ne var ki, bu tartışmalar bugüne kadar bir bilimsel araştırma konusu yapılmadı ve tarafların yazdıkları ışığında mukayese edilmedi. Bu makalede, VIII. Taşnak kongresi gündemi ve Ermenilerin yol haritası üzerindeki görüşmelerin perde arkası, kongreye katılan önemli bazı Ermeni siyasi liderlerinin son zamanlarda ortaya çıkan hatıraları ve yeni yayınlanan arşiv belgeleri ışığında değerlendirilecektir.

Ayrıca soykırım tezine karşı olan bazı yazarların, bu kongrede Osmanlı hükümetinin temsil edilip edilmediğine dair yıllarca sürdürdükleri tartışma da kapsamlı bir şekilde irdelenecektir. Diğer taraftan çoğunluğu Ermeni kökenli olan soykırım tezini savunan bazı tarihçilerin Osmanlı Devleti'nin kongreye Taşnaklarla görüşme yapmak üzere özel bir heyet gönderdiği iddiası da derinlemesine incelenecektir. Ayrıca, Taşnak Kongresi'nde Ermenilerin Rusya tarafında savaşmak üzere faaliyet yürüttükleri, silahlandıkları ve işgal kuvvetlerine yardımcı olduklarına dair sızan bilgilerin güvenilirliği meselesi de ele alınacaktır.

Kongreye Osmanlı heyetinin katılımına dair tartışmalara geçmeden önce VIII. Taşnak Kongresinin gündemi, kararları ve sonuçları hakkında yapılan tartışmaları özetlemek yararlı olacaktır. Bazı tarihçilere göre Batı Ermenilerini temsilen Taşnak Partisi, kongre esnasında yapılan görüşmelerde Avrupa'da patlak veren Dünya Savaşında Osmanlı Devleti'ni tarafsız kalmaya çağırmıştı. Bununla

6 Kaligian, Armenian Organization, s. 220.

7 Christopher J Walker, Armenia: The Survival of a Nation, (London: Palgrave Macmillan, 1990), s. 135. Rusya'nın Erzurum konsolosu A. A. Adamov raporlarında Osmanlı'nın savaşa girmesinden önce bile Osmanlı Ermenilerinin sabırsızlıkla kurtarıcı Rus askerini beklediğini yazıyor. Aktaran Sean McMeekin, The Russian Origins of the First World War, (Cambridge, Mass./London: The Belknap Press of Harward University Press, 2011), s. 164. Ermeni Rus ittifakına dair bazı belge örnekleri için bkz. Osmanlı Belgelerinde Ermeni-Rus İlişkileri, (Ankara: Devlet Arşivleri Genel Müdürlüğü, 2006), s. 75, 85, 87, 89. 
birlikte, eğer Osmanlı Devleti savaşa girerse, Taşnak Partisi mensuplarını vatandaşlık görevlerini yerine getirmeye çağıracaktı. ${ }^{8}$ Edward Erickson'a göre ise kongrede özellikle Batı Ermenileri her Ermeni'nin kendi ülkesine karşı vatandaşlık görevini yapmasının daha doğru olacağı görüşünü savunmuşlardı. ${ }^{9}$ Yani Osmanlı Ermenileri de, Rusya vatandaşı Ermeniler de tebaası oldukları devletlerine sadık olacaklard. ${ }^{10}$

Soykırım tezini reddeden tarihçiler ise genel olarak Esat Uras kaynaklı olmak üzere Ermenilerin VIII. Taşnak Kongresi kararları hakkında çok farklı bir yaklaşımda bulunmaktadır. Buna göre; Taşnaksutyun Kongresi üyeleri, kongrede Rusya ile birlikte hareket etme kararı almışlardı. Bunun yanı sıra Esat Uras, İttihat ve Terakki'nin kongreye Ermenilerle anlaşmaları, özerklik teklifi veya savaşta yardımlarını temin amacıyla bir resmi heyet gönderdiğine dair Taşnak iddialarını kesinlikle kabul etmemektedir. Esat Uras'a göre böyle bir heyetin Erzurum’a gönderildiğine dair " $n$ e bir kayıt ve ne de bir bilgi" vardır. ${ }^{11}$ Bu temelsiz iddia savaştan çok sonra, ilk defa 1920 'de, İstanbul'da Taşnaklar tarafından yayımlanan bir eserde ortaya atılmıştır. ${ }^{12}$ Hatta bu eserde Türk hükümetinin kongreye "delegeler" gönderdiği, bunların kongreye "kabul" olundukları ve kongre kapanmak üzere iken yapılan görüşmelerde Türk delegelerin "Ermeni Taşnaksutyun komitesi Rusya'da bir ibtilâl çıkarır ve bu suretle Osmanlı ordusuna, Kafkasya'y işgaline yardım ederse, Osmanl hükümetinin Ermenistan'a mubtariyet vereceğini vaad" ettikleri iddia olunmaktadır. ${ }^{13}$ Uras, bu teklif karşısında Ermenilerin Osmanlı delegelerine devletin savaşta tarafsız kalmasını tavsiye ettikleri, fakat savaşa girilirse

8 Bu konudaki iddialar için şu eserlere bakılabilir: Karekin Pastermadjian, Why Armenia Should be Free, (Boston: Hairenik Publishing Company, 1918), s. 17; Richard G. Hovannisian (ed.), The Armenian People from Ancient to Modern Times, II: Foreign Dominion to Statehood, The Fifteenth Century to the Twentieth Century, (New York: St. Martin's Press, 1997).

9 Edward J. Erickson, Ottomans and Armenians: A Study in Counterinsurgency, (New York: Palgrave Macmillan, 2013), s. 118-121.

10 Ermenilerin büyük ölçüde İmparatorluğa sadık oldukları tezleri için bkz. Hovannisian (ed.), The Armenian People, s. 234-35; Kaligian, Armenian Organization, s. 227-36; M. Şükrü Hanioğlu, A Brief History of the Late Ottoman Empire, (Princeton, NJ: Princeton University Press, 2008), s. 197-202.

11 Esat Uras, Tarihte Ermeniler ve Ermeni Meselesi, (Ankara: Türkiye Matbaacılık ve Gazetecilik, 1950), s. 589.

12 The Regeneration of Armenia: The Fight for Freedom (İstanbul: Taşnaksutyun Neşriyatından 1920), s. 45. Aktaran Uras, Taribte Ermeniler, s. 590.

13 Uras, Taribte Ermeniler, s. 589. 
de Ermenilerin her ne kadar İtilaf devletlerine yakınlık hissetseler bile vatandaş olarak Osmanlı ordusuna karşı olan vazifelerini yapacaklarını söylediklerinin de gerçeği yansıtmadığını iddia etmektedir. Osmanlı Ermenilerinin Rusya'daki soydaşlarının memleketlerine karşı olan vazifelerini ifâdan men edemeyeceklerine dair açıklamalarını da kabul etmediğini belirtir. ${ }^{14}$

Bununla birlikte son yapılan çalışmalar Erzurum'da düzenlediği kongre esnasında orada bir Türk "heyeti" olduğuna işaret etmektedir. Heyetler arasında ne konuşulduğu ise yine muammadır. Görüldüğü gibi Taşnakların Erzurum'da toplanan VIII. Kongresinde aldıkları kritik kararlar hakkında Esat Uras'ın verdiği ve Türkiye'de çok sayıda tarihçinin sorgusuz kabul ettiği bilgiler Ermeni araştırmacıların görüşleriyle tamamen çelişmektedir. ${ }^{15}$

\section{Osmanlı Devleti VIII. Taşnak Kongresi'ne heyet gönderdi mi?}

Yukarıda da belirtildiği gibi Ermeni tarihi araştırmalarının öncülerinden birisi olan Esat Uras, Osmanlı hükümetini temsilen kongreye bir heyet katılımının söz konusu olmadığını ileri sürmüş ve katılım hakkındaki iddiaların tamamının Ermenilere ait olduğunu belirtmiştir. Buna karşılık kongreye katılan Vahan Minakhorian, A. [Arshak] Vramian, ${ }^{16}$ Rostom [Stepan Zorian] ${ }^{17}$ ve

14 Uras, Taribte Ermeniler, s. 589.

15 Esat Uras’ın görüşleri doğrultusunda Taşnak kongresini değerlendirenler için bkz. Halil Kemâl Türközü, “Taşnak Partisinin 8'inci Kongresi”, Belgelerle Türk Tarihi Dergisi, Dün/ Bugün/Yarın, 12 (1986), s. 69; (Hatırlatmak isterim ki Türközü aslında Erdal İlter’in müstear adıdır) Erdal İlter, “Ermenilerin Tehciri ve Türkler’in Göçü (1915-1918)”, Ermeni Araştırmaları, 9 (2003), s. 30. Kaligian, Esat Uras’ın eserinin güvenilir olamayacağını çünkü Ermeniceden yapılan tercümelerin eksik ve kasıtlı olarak değiştirilmiş olduğunu iddia etmektedir. Dikran Kaligian, "Anatomy of Denial: Manipulating Sources and Manufacturing a Rebellion,” Genocide Studies International, 8/2 (2014), s. 210.

161871 doğumlu Arshak Vramian, Taşnak Partisi Merkez Karar Yönetim Kurulu üyesi olup, Van şehrinden milletvekili seçilerek Osmanlı meclisine girmişti. Vramian, Erzurum'da yapılan VIII. Taşnak Kongresinde etkili liderlerden birisi olarak öne çıkmış, Osmanlı Devleti'nin savaşa dâhil olmasından sonra Van şehrine giderek isyancılara katılmıştı. 1915 yılı Nisan ayında aynı zamanda sınıf arkadaşı olan Van Valisi Cevdet Bey'in emriyle yakalanarak gözetim altına alınmış ve kısa bir süre sonra da öldüğü açıklanmıştır. Bkz. Clarence D. Ussher, An American Physician in Turkey: A Narrative of Adventures in Peace \& War, (Boston and New York: Houghton Mifflin Company, 1917), s. 233-36. Ayrica bkz. Antranig Chalabian, General Andranik and the Armenian Revolutionary Movement, (Melrose: 1988), s. 215.

17 Kod adı Rosdom olup, Taşnakların üç kurucusundan biridir. Aslen Erivan'da doğmuştur. 
Aknuni ${ }^{18}$ [Khachadour Malumian] gibi çok önemli bazı Ermenilerin hatıraları veya onlardan nakledilenler, Osmanlı hükümetini ve/veya İttihat ve Terakki'yi temsil eden bir Türk delegasyonunun Erzurum'da bulunduğunu kanıtlamaktadır. Hatta bu heyetin Taşnak Partisine özerk bir Ermeni bölgesi teklifi yaptığı ileri sürülmektedir. ${ }^{19}$ Kongreye katılım konusunda tarihçiler arasındaki bu tartışma, bugüne kadar kısır bir tartışma olarak kalmıştır. Çünkü taraflar ikna edici bir delil ortaya koymayı başaramamışlardır. Ancak, son zamanlarda yayınlanan bazı hatırat, makale ve tezler ${ }^{20}$ konuya dair yeni kanıtları gün yüzüne çıkartmış ve Erzurum'da ITC ile Taşnak Kongre üyeleri arasında bir görüşme olduğunu ortaya koymuştur.

Öncelikle ifade edilmelidir ki, yeni bilgi sahibi olduğumuz bazı hatıralar, Taşnak kongresine katılan Ermeni delegelere aittir. ${ }^{21} \mathrm{Bu}$ hatıratlardan ilki Ermeni Taşnak delegelerinden Vahan Minakhorian'a aittir. ${ }^{22}$ Vahan Minakhorian'a göre Ağustos 1914 başlarında Erzurum'da yapılan Taşnak Kongresi'ne İttihat ve Terakki Partisi Genel Sekreteri Bahaeddin Şakir Bey ve Nazım Bey, maiyetindeki bir heyetle katılmıştır. Minakhorian'ın iddiasına göre, Bahaeddin Şakir Bey "resmi bir görevli olarak" Erzurum’a gelmiş ve savaşta Ermenilerin alacağı tutum hakkında bizzat kendisinin de içinde olduğu Taşnak heyetiyle görüşmeler yapmıştır. Dolayısıyla Minakhorian, hem İttihat ve Terakki Partisinin iki önemli isminin o sırada kongrede olduğunu belirtmekte hem de Osmanlı Devleti'nin dâhil olmasının an meselesi olduğu, I. Dünya Savaşı'nda Ermenilerin hangi safta yer alacağına dair bu heyetle Taşnak Partisi mensupları arasında bazı görüşmeler yapıldığını kaydetmektedir.

Ömrü Bulgaristan ve Makdeonya’da Osmanlı ordularına karşı örgütlenme ve mücadele ile geçmiştir. Aynı zamanda ünlü Ermenice gazete Droshag Journal'in da editörüdür. Bkz. Chalabian, General Andranik, s. 215.

18 Muğla doğumlu bir gazeteci ve politikacıdır. Osmanlı devletine sadık ve Talat Paşàya yakın bir kişi olduğu için hatıratı ve yazdıkları dikkate değerdir. Aynı zamanda Taşnak Partisi'nden Van mebusu seçilmiştir. Uzun süre Taşnak Partisi İstanbul bürosu başkanlığını yapmıştır. Mushak ve Droshak gazetelerinin editörü olarak da şöhreti vardır. The Armenian Question, Encyclopedia, ed. Acad. K. Khudaverdyan, (Erivan: 1996), s. 26.

19 Kaligian, Armenian Organization, s. 220.

20 Yektan Türkyılmaz, "Rethinking Genocide: Violence and Victimhood in Eastern Anatolia, 1913-1915” (Ph. D. dissertaion), Duke University, 2011.

21 Ermenilerin hatıratlarını benim için tercüme eden Dr. Garabet Krikor Moumdjian'a teşekkürü bir borç bilirim.

22 Vahan Minakhorian, 1915 Tvakanuh [1915 Y111], (Venice: St. Ghazar, 1949), s. 70. 
Son zamanlarda Osmanlı heyetinde yer aldığı iddia edilen isimler hakkında yapılan tezler ile Teşkilat-ı Mahsusa hakkındaki çalışmalar da, Ağustos başlarında Bahaeddin Şakir Bey’in Erzurum'da olduğunu doğrulamaktadır. Erzurum Vali vekili Cemal Azmi Bey'in, 22 Ağustos 1914 tarihinde Dâhiliye Nezaretine (İçişleri Bakanlığı) gönderdiği bir telgraftan, o sıralarda Dr. Bahaeddin Şakir’in Erzurum'da olduğu anlaşılmaktadır. Ayrıca aynı telgraf onun Erzurum'da Talat Paşa'nın bilgisi dâhilinde bulunduğunu kaydetmektedir. ${ }^{23}$ Bu bilgiyi görüşmelere katılan Ermeni Van Mebusu A. [Arshak] Vramian', Rostom [Stepan Zorian] ${ }^{24}$ ve Aknuni [Khachadour Malumian] gibi bazı Ermeniler de doğrulamaktadır. Vramian”ın başında olduğu Ermeni heyetinin Dr. Bahaeddin Şakir Bey ve Naci Bey ile görüşmeler yaptığı sır değildir. ${ }^{25}$

Özetlemek gerekirse; bir Rusya Ermenisi olan ve Türkçe bilmeyen Minakhorian, ${ }^{26}$ Erzurum'da bir Osmanlı resmi heyetinin kongreye katıldığını ileri sürmektedir. Dr. Vahan Papazian ${ }^{27}$ da hatıralarında Erzurum'da İttihat ve Terakki'nin resmi temsilcileriyle görüşmeler olduğunu belirtiyor. Papazian’a göre görüşmeler, Osmanlı Devleti'nin savaşa girdiği takdirde Ermenilerin tarafsız kalacağının duyulması üzerine gerçekleşmişti. Osmanlı heyetinin amacı, Kafkasya ve Kuzey İran'da Rusyàya karşı bir propaganda kampanyası ve mücadelesi başlatmaktı. Papazian, heyetin Taşnakları Rusya'ya karşı cephe oluşturmak için müzakereler yürütmekle yetkilendirildiğini özellikle ifade ediyor. Papazian görüşülen Osmanlı heyet üyelerini [Ömer] Naci Bey ve Dr. Bahaeddin Şakir olarak belirtmektedir. ${ }^{28}$ Ömer Naci Bey'in, Bahaeddin Şakir ile beraber olduğunu

23 BOA, DH.ŞFR.,D.438, G. 32(1) nolu arşiv belgesini aktaran Ahmet Tetik, Teşkilat-ı Mahsusa (Umur-ı Şarkıyye Dairesi) Tarihi, c. I, (Ankara: Türkiye İş̧ Bankası Yayınları, 2014), s. 269.

24 Kod adı Rosdom olup, Taşnakların üç kurucusundan biridir. Aslen Erivan'da doğmuştur. Ömrü Bulgaristan ve Makedonya'da Osmanlı ordularına karşı örgütlenme ve mücadele ile geçmiştir. Aynı zamanda ünlü Ermenice gazete Droshag Journal'in da editörüdür. Bkz. Chalabian, General Andranik, s. 215.

25 Minakhorian, 1915 Tvakane, s. 69-71.

26 Richard G. Hovannisian, Armenian Van/Vaspurakan, (Los Angeles: UCLA, 2000), s. 212.

27 Dr. Vahan Papazian, Van asıllı bir ailenin oğlu olarak Tebriz’de doğmuş olup, 1908 seçimlerinde Van mebusu seçilmiştir. Bkz. Andre Kevorkian, The Armenian Genocide: A Complete History, (London: I. B. Tauris, 2011), s. 827.

28 Vahan Papazian, "Hamashkharhayin Baderazmuh yev Daroni Ashkharhuh”, [The World War and the Region of Daron/I. Dünya Savaşı ve Daron Bölgesi] Vem, 3/3 (1935), s. 3-9. Papazian'ın görüşlerinden bazıları için ayrıca bkz. Kamuran Gürün, Ermeni Dosyası, (Ankara: Türk Tarih Kurumu, 1983), s. 195. 
Erzurum'un valisinin yukarıda değindiğimiz telgrafı da teyit etmektedir. ${ }^{29}$ Fakat burada Minakhorian'ın heyette bulunduğunu söylediği Nazım'dan söz edilmiyor. Bazı kaynaklarda ise Halil Bey adlı birisinin de heyet üyesi olduğu belirtiliyor. ${ }^{30}$ Bu kişinin Filibeli Hilmi olduğunu yazan kaynaklar da vardır. ${ }^{31}$

Yine VIII. Taşnak kongresine katılan Taşnak Partisi mensuplarından ünlü siyasetçi Simon Vratsian ${ }^{32}$ da hatıratında Erzurum'da yaptıkları kongreye İttihat ve Terakki Partisine mensup 8 delege katıldığını yazmaktadır. Fakat, Vratsian görüşmeye gelenlerden sadece Dr. Bahaeddin Şakir ve Naci Bey'in isimlerini vermektedir. İlginç olan Vratsian'ın gelenlerin "ittihatçıların tam yetkili/fully powered representatives of Ittihad" temsilcileri olduğunu kaydetmesidir. Bu heyetle görüşmeleri Taşnak kongresi dağıldıktan sonra oluşturulan 9 kişilik Taşnak delegasyonun yürüttüğünü söylemesi de önemlidir. ${ }^{33}$ Yine Vratsian diğerlerinden farklı olarak hatıralarına önemli bir not eklemiş ve Osmanlı heyetine birkaç düzine Kafkasyalı, İranlı ve Azeri fedainin de refakat ettiğini belirtmiştir. ${ }^{34}$ İttihat ve Terakki Partisi ile Taşnak Partisi arasındaki görüşmeler hakkında verdiği bu detaylar onun bu görüşmeler hakkında ayrıntılı fikir sahibi olduğunu göstermektedir. ${ }^{35}$

29 Tetik, Teşkilat-ı Mahsusa, s. 270.

30 Gaidz F. Minassian, Arsen Avagyan, Ermeniler ve İttihat ve Terakki İşbirliğinden Çatışmaya, çev. Ludmilla Denisenko, Mutlucan Şahan, yay. haz. Rober Koptaş, (İstanbul: Aras, 2005), s. 131-32. Krş. Türkyılmaz, "Rethinking Genocide", s. 159.

31 Önol, “The Eight World Congress”, s. 87. Katılımcılara dair Rusça kayıtlar bu makalede ikna edici bir şekilde kaydedilmiştir.

32 Simon Vratzian 1882'de Nahcivan'ın Büyük Sala köyünde doğmuştur. Taşnak Partisine katılmış ve lider kadrosuna kadar yükselmiştir. Savaş sonrasında kurulan Demokratik Ermeni Cumhuriyeti'nin 4. Başbakanı olarak görev yapmıştır. 1928 yılında bir hatırat yayınlamıştır. Simon Vratzian, Hayasdani Hanrabedutiune [The Republic of Armenia/Ermenistan Cumhuriyeti], (Paris, 1928). Hakkında bilgi için bkz. Michael Bobelian, Children of Armenia: A Forgotten Genocide and the Century-long Struggle for Justice, (New York: Simon and Schuster, 2009), s. 91.

33 Simon Vratsian, Armenia and the Armenian Question, çev. James G. Mandalian, (Boston: Hairenik Publishing Company, 1943), s. 25. Vratzian, Hayasdani Hanrabedutiune, s. 8. Ayrıca Taşnak belgelerine dayanarak kongre hakkında bilgi veren Kaligian'da kongre sonrası kalan işleri tamamlamak üzere seçilen 9 kişilik bir komiteden söz etmektedir. Kaligian, Armenian Organization, s. 220.

34 Vratzian'dan aktaran Türkyılmaz, "Rethinking Genocide”, s. 156, not 103.

35 Simon Vratzian, Hayasdani Hanrabedutiune s. 8-9. Richard G. Hovannisian, "Simon Vratzian and Armenian Nationalism”, Middle Eastern Studies, 5/3 (1969), s. 192-220. 
Yine çete reisi Antranik Ozanian hakkında yazılan bir biyografide, Naci Bey ve Bahaeddin Şakir'in Jön Türkleri "temsilen" ve Taşnak Partisi ile "müzakere etmek" için Erzurum'a geldikleri kaydedilmektedir. ${ }^{36}$ Diğer taraftan o sıralarda İstanbul'da bulunan Karekin Pastırmacıyan da eserinde, Erzurum'a bir İttihatçı heyetin gittiğini şu satırlarında ifade etmektedir: "1914 Ağustos’unun son günlerinde, 28 kişilik bir Türk heyeti Konstantinopol'den Ermenistan'a hareket etti. Bu özel heyetin liderleri İttihat ve Terakki Partisi’nin önde gelenlerinden Ömer Naci Bey, Dr. Bahaeddin Şakir ve Teğmen Filibeli Hilmi ${ }^{37}$ idi. Amaçları Rusya ve müttefiklerine karşı, Yakın Doğu'daki bütün ırklar arasında Pan-İslamik ve PanTuranik akım organize etmekti. Bu heyette Kürtler, İranlılar, Gürcüler, Çeçenler, Lezgiler, Çerkesler ve Kafkas Tatarları gibi doğu ırklarının hepsinin birer temsilcisi yer alıyordu; sadece Ermenilerin bir temsilcisi yoktu. Ermeni Milli Örgütü aynı günlerde Erzurum'da, yıllık kongre toplantısı yapmaktaydı." 38

Diğer taraftan kongre toplandığı sırada Erzurum'da bulunmayan Karekin Pastırmacıyan, Taşnaklarla İttihatçıların görüşmesini "resmi” 39 olarak nitelendirmektedir. Amerika Birleşik Devletleri'nin Boston şehrinde bulunan Taşnaksutyun Arşivlerini kullanan çok az sayıda araştırmacıdan birisi olan Dikran M. Kaligian da İttihat ve Terakki ile Taşnak Partisi görüşmesinin kesin olarak yapıldığını savunmaktadır. Kaligian’a göre Taşnak kongresi toplantı halindeyken Dr. Bahaeddin Şakir ve Naci Bey Erzurum'a gelmiş ve kongre sonunda oluşturulan komitenin üyelerinden Rosdom, Aknuni ve Vramian ile üç gün süren bazı görüşmeler yapmıştır. ${ }^{40}$ Rus resmi kayıtları da görüşmeyi doğrulamaktadır. ${ }^{41}$

Esat Uras'in çizgisinde olan ve Taşnaklarla görüşmeleri kabul etmeyen cephede ise durum çok daha karmaşıktır. Bu cephenin en hararetli temsilcileri olarak Erdal İlter ve Halil Kemal Türközü’nü sayabiliriz. ${ }^{42}$ Bu cephede Esat Uras’ın

36 Chalabian, General Andranik, s. 215. Burada İttihatçıların kongre bitmek üzereyken Erzurum'a geldikleri kesin bir şekilde ifade edilmektedir.

37 Hilmi ismi birkaç hatırat ve belgede de geçmektedir. Bkz. Ruben Ter Minassian, Hay Heghapokhagani Me Hishadagnere, c. VII, (Tehran: 1982), s. 126-27. Osmanlı arşiv belgelerinde Müfettiş Hilmi Bey’in Bahaeddin Şakir ile beraber olduğu görülmektedir. Bkz. Tetik, Teşkilat-ı Mahsusa, s. 275 ve 295.

38 Pastermadjian, Why Armenia Should be Free, s. 16.

39 Pastermadjian, Why Armenia Should be Free, s. 17.

40 Kaligian, Armenian Organization, s. 220.

41 Önol, “The Eight World Congress”, s. 788, dipnot 46.

$42 \mathrm{Bu}$ cepheye en son katılanlardan birisi Guenter Lewy oldu. Bkz. Guenter Lewy, The 
görüşlerine tamamen katılan, karşı çıan ve görüşmeleri kısmen kabul edenler de vardır. Nitekim Kamuran Gürün, Clair Price'ın eserinden alıntı yaparak, Erzurum'da VIII. Taşnak Kongresi toplantısına İttihat ve Terakki Partisini temsilen bazı kimselerin katılmış olabileceğini ve kongre devam ettiği sırada taraflar arasında bazı görüşmeler yapılmış olabileceğini belirtiyor. ${ }^{43}$ Erickson ise kongre sırasında veya sonrasında Dr. Bahaeddin Şakir'in Ermenilerle görüştüğünü kabul etmekle birlikte bu görüşmenin İstanbul'un yetkilendirmesi ve/veya bilgisi dâhilinde olup olmadığının tartışma konusu olduğunu belirtmektedir. ${ }^{44} \mathrm{O}$ halde bu görüş farklılığı nereden kaynaklanmaktadır? Bu görüş farklılıklarının bize göre birkaç sebebi bulunmaktadır.

Öncelikle tarafların kaynaklarına göz atmak faydalı olacaktır. Birinci gruptan, yani taraflar arasında görüşme olduğunu reddedenlerden başlarsak; Uras, Türközü ve ondan naklen İlter gibi araştırmacılar kongreye Osmanlı temsilcilerinin katıldığını ve özerk Ermenistan teklifi yapıldığını kesin olarak reddediyorlar. ${ }^{45}$ Ancak bu araştırmacıların ret gerekçelerinin ikna edici olduğunu söylemek mümkün değildir. Örneğin Halil Kemal Türközünnün en önemli kanıtlarından birisi Taşnak Partisinin 1914'te Erzurum'da toplanan VIII. Genel Kongresine ait karar defterinde İttihat ve Terakki heyetinin isimlerinin yer almamasıdır. Diğer bir kanıtı ise İttihat ve Terakki Hükümeti’nin İngilizlerin Mavi Kitabına karşlık olarak yazdığı "Beyaz Kitap"ta kongreye katılmaya dair tek bir satır bile bulunmamasıdır. ${ }^{46}$ Öncelikle kongrenin bir Taşnak Partisi kongresi olduğu değerlendirildiğinde, karar defterinde İttihat ve Terakki sözde heyetine dair kayıt bulunmaması kanaatimizce mantıklıdır. İttihatçılar kongreye delege olarak katılmamışlardır. Sadece çok önemli Taşnak liderlerinin bulunduğu bir ortamda bazı önemli görüşmeler yaptıkları anlaşılmaktadır. Tarık Zafer Tunaya da bu görüştedir ve İttihat ve Terakki'yi temsilen kongreye Dr. Bahaeddin Şakir ve Azerbaycan Müfettişi Ömer Naci Bey’in katıldığını belirtir. ${ }^{47}$ Burada Tunaya’nın ifadesinden "kongreye delege olarak katıldılar" anlamını çıkartmak yanlıştır.

Armenian Massacres in Ottoman Turkey: A Disputed Genocide, (Salt Lake City: University of Utah Press, 2005), s. 100-101.

43 Gürün, Ermeni Dosyası, s. 281.

44 Erickson, Ottomans and Armenians, s. 120.

45 Erdal İlter, Türkiye’de Sosyalist Ermeniler’in Silablanma Faaliyetleri ve Milli Mücadelède Ermeniler 1890-1923, (Ankara: Turhan Kitabevi, 2005), s. 53-55, 61-62, 64-66.

46 Türközü, “Taşnak Partisinin 8 nci Kongresi”, s. 12.

47 Tarık Zafer Tunaya, Türkiye’de Siyasi Partiler, c. III: İttihat ve Terakki, Bir Çağın, Bir Kuşağın, Bir Partinin Taribi, (İstanbul: İletişim Yayınları, 2007), s. 648. 
Diğer taraftan Erzurum'a gittiği iddia edilen İttihatçılar hakkında yapılan bazı biyografik çalışmalar Türközü ve Uras’ın görüşlerini çürütmektedir. Bu biyografik çalışmalardan birisi Dr. Bahaeddin Şakir hakkında olup Dr. Alaattin Uca tarafından yapılmışıır. ${ }^{48}$ Dr. Uca’ya göre Dr. Bahaeddin Şakir, 1914 yılında Erzurum'da yapılan Ermeni Taşnak Kongresi'ne İttihat ve Terakki'nin "kâtib-i mesulü” olarak katılmıştır. ${ }^{49}$ Hatta Uca’ya göre, Dr. Bahaeddin Şakir Bey, bu kongreye Ermenilerin Rusya ile işbirliğini önlemek ve Ruslara karşı Osmanlı Devleti’nin yanında mücadele etmelerini sağlamak gibi “özel bir görev” üstlenerek katılmış, fakat bir sonuç elde edememiştir. ${ }^{50} \mathrm{Bu}$ ifade tartışmasız bir şekilde Dr. Bahaeddin Şakir başkanlığında bir İttihatçı heyetin Erzurum'da bulunduğunu ve Taşnak Kongresi esnasında görüşmeler yaptığını ortaya koymaktadır. Aynı zamanda Alaattin Uca’nın bu tespiti kongreye katılan Ermeni siyasetçilerinin hatıralarıyla da uyuşmaktadır. Bu durum, Erzurum'daki Taşnak Kongresine İttihatçıların heyet gönderdiği tezini savunan Kamuran Gürün ${ }^{51}$ ve Salahi R. Sonyel ${ }^{52}$ gibi araştırmacıları doğrulamaktadır.

Bu bakımdan Alaattin Uca’nın katılım ile ilgili verdiği bilgi ilginç ve önemlidir. Zira bu bilginin ortaya çıkmasından önce İttihatçıların Erzurum'da Taşnaklarla görüştügüunü ileri sürenlerin temel kaynakları gazeteci Clair Price ${ }^{53}$ ve İngiliz tarihçi Arnold Toynbee ${ }^{54}$ idi. Özellikle Clair Price kongreye İttihatçıların katılımıyla ilgili olarak eserinde çok açık bir ifadeyle, "1914 sonbaharında Türkler Erzurum'da toplanan Osmanlı Ermenilerinin Milli Kongresine bir heyet

48 Alaattin Uca, "İttihad ve Terakki Liderlerinden Doktor Bahaeddin Şakir Bey” (Doktora Tezi), Atatürk Üniversitesi, 2009, s. 253-54.

49 Uca, "İttihad ve Terakki", s. 253-54. Dr. Bahaeddin Şakir hakkında bir başka biyografik eserde de onun Erzurum'daki kongreye katıldığı belirtiliyor, fakat başka hiçbir detay yer almıyor. Bkz. Hikmet Çiçek, Dr. Bahattin Şakir İttihat ve Terakki'den Teşkilatı Mahsusa’ya Bir Türk Jakobeni, (İstanbul: Kaynak Yayınları, 2007), s. 122.

50 Taner Akçam ise Bahaeddin Şakir ve Ömer Naci gibi İttihat üyelerinin Erzurum'da kongreye katılmak amacıyla değil ve bölgede Teşkilat-ı Mahsusa birliklerini oluşturmak amacıyla bulunduklarını, Taşnak 8. Kongresini ise bu gizli amacı örtmek amacıyla kullandıklarını ileri sürmektedir. Ancak kaynakları ikna edici değildir. Bkz. Taner Akçam, İnsan Hakları ve Ermeni Sorunu, (Ankara: İmge Kitabevi, 2002), s. 240.

51 Gürün, Ermeni Dosyası, s. 195.

52 Salahi R. Sonyel, The Turco-Armenian Imbroglio, Prospects for Reconciliation, (London: Cyprus Turkish Association, 2005), s. 67.

53 Clair Price, The Rebirth of Turkey, (New York: Thomas Seltzer, 1923), s. 5.

54 F.O. 371/3404, No: 162647, s. 4'ten aktaran Gürün, Ermeni Dosyası, s. 195. 
gönderdiler" bilgisini verir. Ancak şunu ifade etmeliyim ki gerek Arnold Toynbee ve gerekse Clair Price'ın yazdıkları, sadece duyumlara ve özellikle Ermenilerin verdiği bilgilere dayanmaktadır. ${ }^{55}$

Ne var ki Alaattin Uca'nın Erzurum'a giden İttihatçı heyet ve görüşmeler hakkında verdiği bilgiler, ilmi bir süzgeçten geçirildiğinde pek çok çelişkiyi de içinde barındırmaktadır. Şöyle ki, Dr. Bahaeddin Şakir'in Taşnak heyetiyle resmi olarak Erzurum'da görüşmeler yaptığını yazan Uca, doktora tezinin ilerleyen satırlarında onun "Erzurum'da Ermeni temsilcileriyle bir kongre yaptığın"”6 yazmaktadır. Kabul etmek gerekir ki, bu şekilde bir ifade yanlış anlaşılmaya müsaittir. Çünkü Bahaeddin Şakir, Erzurum'da Taşnaklarla bir "kongre” yapmamış, sadece görüşmelerde bulunmuştur. Eğer atıf yaptığı belgelerdeki ifade de bu şekilde ise, şunu kesin olarak tespit etmeliyiz ki, İttihat ve Terakki Partisini temsilen Dr. Bahaeddin Şakir ile Ermeniler arasında Erzurum'da bazı görüşmeler gerçekleşmiştir. Ancak Dr. Uca'nın tezinde Dr. Bahaeddin Şakir'in Erzurum'da bulunuşu ve temasları hakkındaki bilgiler, başka bazı önemli soruları ve sorunları da beraberinde getirmektedir. Dr. Uca, tezinin bir başka yerinde; "Elbette ki Dr. Bahaeddin Şakir Bey, Ermeni kongresine katılmak için İstanbul'dan Erzurum’a gelmemiştir. Zaten böyle bir zorunluluğu da yoktur” demektedir. Başka bir ifadeyle Dr. Uca, Dr. Bahaeddin Şakir'in özellikle Taşnak kongresine katılmak için Erzurum’a geldiğini söylemenin doğru olmayacağını kaydetmektedir. Ona göre Dr. Bahaeddin Şakir "Teşkilat-1 Mahsusa görevleri doğrultusunda Erzurum'da" bulunmaktayd..$^{57}$ Nitekim Dr. Bahaeddin Şakir de maiyetiyle birlikte Erzurum'da bulunan "Kafkasya Türkleri” arasında bir isyan başlatmak için yola çıktıklarını, Rusya savaşa girdiği takdirde de ordunun gerisinde onları bozmak ve demoralize etmek için çalışacaklarını rapor ediyordu. ${ }^{58}$ Papazian da aynı bilgiyi aktarmaktadır. ${ }^{59}$

Bu görüşü ile Uca, Akçam’ın iddiasını desteklemektedir. Ne var ki, elimizdeki diğer bilgiler, Dr. Bahaeddin Şakir ve diğerlerinin kongreye katılmak için olmasa da görüşmeler yapmak için geldiklerini doğrulamaktadır. Başka bir görev gereği Erzurum'da bulunmuş olsalardı, Bahaeddin Şakir ve yanındakiler bu kadar

55 Arnold J. Toynbee ve James Bryce, The Treatment of Armenians in the Ottoman Empire: Documents Presented to Viscount Grey of Fallodon, Secretary of State for Foreign Affairs (London: Hodder \& Stoughton, 1916), s. 631.

56 Uca, "İttihad ve Terakki", s. 253.

57 Uca, "İttihad ve Terakki”, s. 258.

58 Tetik, Teşkilat-ı Mahsusa, s. 271.

59 Papazian, "Hamashkharhayin Baderazmuh", s. 9. 
önemli bir konuda Taşnak temsilcileriyle özel bir görüşme yapamazlardı. Dolayısıyla Uca’nın ifadelerinde çok önemli çelişkiler yer almaktadır.

Bu tespiti yaptıktan sonra yapılan görüşmelerin içeriği hakkındaki iddiaları da ana hatlarıyla tartışmak gerekmektedir.

\section{İttihatçılarla Taşnakların Erzurum Buluşmasının Perde Arkası}

Dr. Bahaeddin Şakir'in, Taşnak Partisi'nin VIII. Kongresinin yapıldığı günlerde, bir grup İttihatçı ile Erzurum'da bulunduğu ve Taşnaklarla bir görüşme yaptığı konusunu açıklığa kavuşturduktan sonra, yapılan görüşmelerin mahiyeti ve alınan kararların önemine dikkat çekmek istiyoruz. Esasen bu konuda da araştırmacılar arasında çok farklı görüşler bulunmaktadır. Burada, bu görüşlerin temelleri ve Türk-Ermeni ilişkilerine etkileri detaylı bir şekilde değerlendirilecektir. Ancak Erzurum'da yaşananlara geçmeden önce, Ermenilerin savaşta ortak bir politika belirlemek amacıyla İstanbul'da Patrikhane'nin öncülüğünde bir toplantı yaptığını da belirtmek gerekir.

Patrik Zaven'in belirttiğine göre, Mart-Nisan aylarında yapılan toplantılara Taşnaksutyun, Hınçak, Ramgavar, Veragaz, Mihal Hınçak ve Ermeni Milli Komitesi üyeleri davet edilmiştir. Kamuya yansıdığına göre toplantıda Osmanlı Ermenilerine vatana ihanet etmemeleri, dış ülkelerin etkisinde kalmamaları ve askerliklerini yapmaları tavsiye edilmiştir. ${ }^{60}$ Ancak bu toplantıda farklı Ermeni grupların birbiriyle örtüşmeyen görüşleri savundukları da bazı kaynaklarda kaydedilmektedir. Örneğin Hınçak komitesi temsilcilerinin İstanbul'daki toplantıda Patrikhane ile beraber hareket edeceklerini belirttikleri de iddia edilmektedir. Hâlbuki Paris'te bulunan Sosyal Demokrat Hınçakyan Komitesi Genel Merkezi'nden 1914 Ağustos ayında yapılan bir açıklamada, Partinin, İtilaf Devletleri'nin bilhassa Rusya’nın müttefiki sıfatıyla savaşta yer alacaklarını ilan ettiklerini görüyoruz. Öte yandan Patrik Zaven'in hatıralarından öğrendiğimize göre Patrikhane bu toplantılarda İstanbul İtilafnâmesi (8 Şubat 1914) ile başlayan reform sürecinin sürmesinden yana olduğunu beyan etmişti. Bu yüzden Taşnaksutyun ile Patrihane arasında fikir ayrilığı oluşmuştu.

Bu süreçte, Taşnakların Patrikhaneyi kontrol altına alma girişimleri yaşanmışsa da başarısızlıkla sonuçlanmıştır. Ancak Avrupa'da savaşın başlaması koşulları tamamen değiştirdiği için Patrikhane, reform sürecinin Avrupa ülkeleri

60 Mim Kemal Öke, The Armenian Question, (Ankara: Türk Tarih Kurumu, 2001), s. 108. 
himayesinde sürmesini arzu ediyordu. Osmanlı hükümeti ise Ermeni ahalinin hükümete güvenmesini, diş güçleri bertaraf etmesini ve reform sürecinin bir hükümet icraatı olarak sürmesine razı olmasını istiyordu. Ne Patrikhane ne de Ermeni Ulusal Delegasyonu hükümetin bu teklifini kabul etti. ${ }^{61}$ Bununla birlikte Patrik Zaven ihtiyatlı davranılmasını tavsiye ediyordu. Aksi durumda Ermenilerin dış güçlerle işbirliği olmasından zaten rahatsız olan İttihatçıların intikam almaya yöneleceklerini düşünüyor ve iktidara bahane verilmemesini savunuyordu. Bu düşüncesini iletmek üzere, 1914 yılının Temmuz - Ağustos aylarında Dr. N. Daghavarian'ı Tiflis'e gönderdi. Daghavarian görüşmelerden sonuç alamadı. Tam tersine, Eçmiyadzinden gelen Khosrov Behrigian'ın Patrik Zaven’e ilettiği bilgilere göre, Rusya Ermenileri gönüllü birlikler oluşturarak Rus ordusuna katılmaya başlamıştı. Böylece Osmanlı devletine karşı top yekûn bir savaş başlatarak Türk Ermenilerini özgürleştirmeye hazırlanmaktaydılar. Patrik Zaven'in kişisel olarak Müttefiklere yakın olduğunu ifade etmesi de anlam taşımıyordu. Ayrıca Patrikhane, Doğu Anadolu'da Ermenilerin İtilaf devletleri ve Rusya'ya sempatilerine dair raporlar almaktayd $1 .{ }^{62}$

İstanbul'daki toplantıya katılan Taşnaksutyun temsilcilerinin ise olayların seyrine göre tavır almayı tercih ettikleri görülmektedir. Özellikle Taşnakların Osmanlı hükümetinin aldığı seferberlik kararına başından itibaren şiddetle karşı koydukları kendi iç yazışmalarından tespit edilebilmektedir. ${ }^{63}$ Ayrıca bu yazışmalarda, parti kararının VIII. Erzurum Taşnak Kongresinde alınacağına da işaret edilmektedir. Bu bakımdan Erzurum'daki Taşnak Kongresi esnasındaki görüşmeler ve alınan kararların kesin olarak tespiti, konunun aydınlığa kavuşması için büyük önem taşımaktadır.

Ermeni soykırım tezine karşı çıkan gurubun tarih yazımında, Birinci Dünya Savaşı sırasında Ermenilerin vatandaşı oldukları Osmanlı Devleti’ne karşı Rusya ile birlikte mücadele ettikleri tezi genel kabul görmüştür. Türközü ve İlter gibi çok sayıda araştırmacıya göre Ermeniler, Osmanlı Devleti seferberlik ilan etmeden bir süre önce, Osmanlı Hükümeti'nin Birinci Dünya Savaşı'na katılması halinde, kendilerinin Rusya ile nasıl bir işbirliği yapabileceklerini müzakere etmek

61 Zaven Der Yeghiayan, My Patriarchal Memoirs, çev. Ared Misırlıyan, haz. Vatche Ghazarian, (Barrington: Mayreni Publ., 2002), s. 32-33.

62 Yeghiayan, My Patriarchal Memoirs, s. 33.

63 Ermeni Komitelerinin Amâl ve Harekât-ı İhtilaliyesi: İlan-ı Meşrutiyet'den Evvel ve Sonra (İstanbul: Matbaa-i Amire, [1332] 1916). 
için Erzurum'da toplanmışlardı. ${ }^{64}$ Yine Salahi R. Sonyel, Mim Kemal Öke gibi bazı tarihçilere göre, iki hafta kadar süren kongrede Osmanlı Devleti'ne karşı cephe alma ve Ruslara katılma kararı çımıştı. ${ }^{65}$ Clair Price ise, Osmanlı Meclis-i Mebusan'ında vekil olan Ermenilerin devlete bağlılıklarını sürdürdüklerini, fakat diğer parti mensuplarının açıkça Osmanlı Devleti harbe girdiği takdirde İtilaf devletleri ile birlikte hareket edeceklerini ilan ettiklerini ileri sürmektedir. Price'a göre, Erzurum'daki gelişmeler şu şekildeydi:

“İstanbul Meclisi’ndeki Ermeni Grubu, Enver Hükümeti 1914'te harbe girerken Erzurum'da kongrelerini yapıyorlardı. Hükümet temsilcileri onları orada ziyaret etti ve ilk hedefi Rusya olan Panturan projesini sundu. Burada Rus Maveray-1 Kafkas'ının taksimi teklif ediliyor, fethedilecek toprakların Ermeniler, Gürcüler ve Tatarlar arasında taksim edilip hepsine Osmanlı hâkimiyeti altında otonomi vaat ediliyordu. Ermeni grubu eğer harp zaruri olursa Osmanlı vatandaşı olarak vazifelerini yapacaklarını, fakat hükümetin tarafsız kalmasını tavsiye edeceklerini söylediler." ${ }^{66}$

Buna karşılık Clair Price’a göre, Taşnakların bazıları da Erzurum'da Ermenilerin özgürlüğü için Rusya tarafında savaşa girmenin tarihi bir fırsat olduğunu düşündüklerini deklare etmişlerdi. ${ }^{67}$ Price'ın bu yazdıkları dışında, soykırım tezini reddeden tarihçilerin VIII. Taşnak Kongresi hakkındaki tutarlı ve eldeki tek kaynağ 1 , bir istihbarat raporudur. ${ }^{68}$

Osmanlı Ordusu Başkumandanlığına 3.Ordu istihbaratından gelen bu rapora göre, Erzurum'da toplanan kongrede Rus-Ermeni antlaşması onaylanmıştır. Duyumlara göre Ruslar, Türkiye'den zapt edecekleri araziyi Ermenilere vererek

64 Türközü, “Taşnak Partisinin 8 nci Kongresi”, s. 12, 69; İlter, "Ermenilerin Tehciri”, s. 30. Bu kongrenin Talat Paşa'nın isteğiyle toplandığı iddia etmek, fazla abartılı olsa gerektir. Bu iddialar için bkz. Yves Ternon, Bir Soykırım Tarihi (20 Yıl Sonra Ermeni Tabusu Davası), (İstanbul: Belge Yayınları, 2000), s. 246. Tunaya, İttihat ve Terakki Cemiyeti, s. 648.

65 Sonyel, The Turco-Armenian Imbroglio, s. 67; Öke, The Armenian Question, s. 108-109. Aslında bu yazarların ve bu konuda görüş belirtenlerin kaynağı Osmanlı Devleti'nin Kırmızı Kitabı olan şu eserdir: Bkz. Ermeni Komitelerinin Amâl ve Harekât-ı İhtilaliyesi.

66 Price, The Rebirth of Turkey, s. 85.

67 Price, The Rebirth of Turkey, s. 85-86.

$68 \mathrm{Bu}$ istihbarat raporunun bir değerlendirmesi için bkz. Justin McCarthy, Esat Arslan, Cemalettin Taşkıran ve Ömer Turan, The Armenian Rebellion at Van, (Salt Lake City: The University of Utah Press, 2006), s. 182. 
onların bağımsızlığını kazanmasını sağlayacaklardı. Yine aynı istihbarata göre Ermeniler aşağıdaki kararları almışlardı:

1. Savaşın ilânına kadar sessiz kalmaya ve boyun eğmeğe devam etmek; fakat bu zaman zarfında Rusya'dan gelecek ve içeriden tedarik edilecek silâhlarla donanmış bir hâle gelmek.

2. Savaş ilân edilirse Türk ordusundaki Ermeni askerlerinin silâhlarıyla birlikte Rus ordusuna katılmaları.

3. Türk ordusunun ilerlemesi durumunda sessizliği muhafaza etmek.

4. Türk ordusu ric'at eder yahut ilerleyemeyecek duruma gelirse, çetelerin derhâl ellerindeki programa uygun olarak ordu gerisinde faaliyete geçmeleri. ${ }^{69}$

Bu belgede ortaya konan görüşler, Ermeni soykırım tezini reddedenler tarafından Ermenilerin Osmanlı devletine ihanetlerinin kanıtı olarak değerlendirilmekte ve genel kabul görmektedir.

Diğer taraftan Rus istihbarat kaynakları da Erzurum Kongresini yakından izlemiş, kongre hakkında üslerine rapor yazmışlardı. Bu raporlardan birisi Lebuk kod adlı Rus gizli servis elemanı tarafından düzenlenmiştir. Bu rapora göre: “Taşnak Partisi'nde, Ermeni sorununun Rusya’nın müdahalesi ile çözümlenmesine ilişkin iki görüş vardı. Bu görüşlerden biri, Ermenistan’ın kaderinin Rusyàya bağlı olduğunu varsayarak Ermeni sorununun çözümünde Rusya’nın müdahalesini gerekli buluyordu. Bu görüşün temsilcileri Hovhannes Tumanyan, Karekin Pastırmacıyan (Armen-Garo) ve Doktor Zavriyev gibi ünlülerdi. Ancak bu görüş doğru bulunmadı. Karşıt görüştekiler ise Rusya’yı Ermeni düşmanı olarak adlandırmaktaydı. Bu görüşü savunanlar, Rusyảnın Ermeni sorununa müdahalesinde, sadece iki amacı olduğunu düşünüyordu: Toprak kazanmak ve Rus mallarının satışı için iyi bir pazar elde etmek. Bu görüşün bazı savunucuları Rostom, Aknuni (Khaçatur Malumyan ve Vramian ile Aram-Paşa (şu andaki Van ili Valisi) idi. Bunlar "Rusya’ya Ermenisiz bir Ermenistan gerek" diyordu. ${ }^{70}$

69 Raporun aslı şu eserde yayınlandı: Documents on Ottoman Armenians, c. II, (Ankara: Prime Ministry Directorate General of Press and Information, 1982), s. $44-54$ ve Osmanlica kopyası s. 55-56. Ayrıca Ermeni Komitelerinin Amâl ve Harekât-ı İhtilaliyesi, s. 96-97.

70 Belge No: 10: GARF. Fon 102. Sayı 244 (1915). Dosya 14. Bölüm. 79 LB. Sayfa 32-32 arkası, 33-33 arkası, 34-34 arkası, 35, 36-36 arkası. Aktaran Natalia Chernichenkina, Rus 
Buna karşılık Ermeni soykırım tezini savunanlar israrla Erzurum'daki Taşnak Kongresinde devlete bağlılık ve vatandaşlığın gereklerinin yerine getirilmesi kararı çıktığı dile getirilmektedir. Dolayısıyla bu çelişkili açıklamaların kaynakları ve tutarlığının analiz edilmesi gereği vardır. Öncelikle bu karışıklığın sebeplerinden birisinin kongreden sonra Taşnaklar adına milletvekili Vramian vasıtasıyla Erzurum valisine iletilen kararlar olduğunu belirtmek gerekir. Bu kararlarda; Osmanlı Hükümeti'nin Rusya'ya savaş ilân etmesi ve Osmanlı ordusunun Kafkasyàya saldırması durumunda, Osmanlı Ermenilerinin devlete sadakatle hizmet edecekleri, Kafkasya Ermenilerinin de iş birliği yapmaya hazır oldukları belirtilmektedir. Hatta bu tarz bir tavrın desteklenmesi için Osmanlı hükümetinin de galibiyetten sonra Ermenistan'ın teşkiline dair güçlü vaatte bulunması gerektiği bizzat Vramian tarafından Vali'ye söylenmiştir. ${ }^{71}$

Bununla birlikte yine Ermeni soykırım tezini savunan tarihçiler arasında kongre kararlarının Erzurum valisine farklı iletildiğini iddia edenler de vardır. Bu konuda Dikran M. Kaligian'ın naklettikleri önemlidir. Yukarıda da kısaca değinildiği gibi Kaligian’a göre, Kongrede İttihat ve Terakki Partisine karşı önemli eleştiriler yapılmış, ama ilişkilerin dondurulmaması yönünde bir fikir birliği de oluşmuştur. ${ }^{72}$ Bu bilgi, Taşnak Kongresine katılan Simon Vratsian'ın yazdıkları ile de örtüşmektedir. ${ }^{73}$ Nitekim Vratsian kongrede alınan kararla bütün parti organlarına devlete bağlı kalınması ve vatandaşlık görevinin yerine getirilmesi konusunda emir verildiğini belirtmektedir. Yine Vratsian’a göre kongrede savaşın hem Osmanlı Devleti hem de Ermeniler için yıkım olacağı endişesiyle, Türkiye'nin savaşta tarafsız kalmaya ikna edilmesi için çalışılması da kararlaştırılmıştı. ${ }^{74}$

Ancak Kaligian' in belirttiği bu husus önemli olmakla beraber savaşta Ermenilerin alacağı tavır konusunda bir açıklık getirmemektedir. Hâlbuki heyetler arasındaki görüşmelere dair yine Kaligian'ın Taşnak arşivlerinden bulduğu bir belge ve Vratsian'ın hatıratında naklettikleri, Dr. Baheddin Şakir'in Taşnaklarla neler konuştuğunu açıklığa kavuşturmaktadır. Vratsian’a göre Taşnaksutyun'a yapılan

İmparatorluk Kayıtlarında Ermeni Sorunu 1912-1917, (Erzurum: Erzincan Üniversitesi Yayınları, 2015), s. 106-108.

71 Documents on Ottoman Armenians, c. II, s. 44.

72 Kaligian, Armenian Organization, s. 220.

73 Simon Vratsian, Armenia and the Armenian Question, (Boston: Hayrenik Publishing Company, 1943).

74 Burada Komite üyelerinin sayısı 7 olarak verilirken Minorkian hatıratında 9 kişi olduğunu belirtmektedir. 
tekliflerden birisi Taşnaksutyun'un Rusya'ya karşı açılacak cepheye katılması idi. Gürcü, Azeri ve Kuzey Kafkasyalı Müslümanlar da bu cepheye katılacaktı. Bu sayede Rusya’nın yenilmesi kaçınılmazdı. Rusya yenilgiye uğratılınca “Türkiye’nin himayesinde Ermenistan, Gürcistan ve Azerilere özerklik vaat ediliyordu. ${ }^{75}$

Güya Osmanlı heyeti, Ermenilere Kafkasya’yı işgal etme niyetinde olmadıklarını belirtmiş ve amaçlarının burada Osmanlı himayesinde özerk bir Ermenistan kurmak olduğunu iletmişlerdi. ${ }^{76}$ Kaligian'ın da paylaştığ 1 bu bilgiler gerçekten İttihatçılar ile Taşnaklar arasında geçen görüşmelerin içeriği hakkında çok değerli bilgileri gün ışığına çıkartmaktadır. Ancak bilgilerin doğruluğunu teyit etmek önemlidir. Bu konuda Osmanlı askeri istihbarat belgelerinde az da olsa bilgi vardır. Teşkilat-ı Mahsusa hakkında son yıllarda önemli arşiv çalışmaları yapan Dr. Ahmet Tetik'in yazdığına göre, Dr. Bahaeddin Şakir ve arkadaşları gerçekten de Erzurum, Van, İran ve Kafkasya bölgesinde bir ihtilâl çıkartmak veya en azından Müslümanları Rusya aleyhine örgütlemek için faaliyet içerisindedirler. Ancak onlar, bölge hakkında topladıkları istihbarat sonucunda, Rusya tamamen yenilgiye uğratılmadan ihtilâl beklemenin boşuna olduğunu değerlendirmişti. ${ }^{77}$

Kaligian'ın kaynağı olan Taşnak arşiv belgelerine göre ise, Dr. Bahaeddin Şakir ve Ömer Naci, görüşmeler esnasında iki muhtemel gelişme hakkında Taşnaksutyun'un tavrının ne olacağını sormuştu: Birincisi; Rusya’nın Osmanlı topraklarını işgal etme ihtimali. İkincisi; Osmanlı ordusunun Rusyaya girmesi ve Rusya'ya karşı Kafkasyåda bir isyanın desteklenmesi. Taşnaksutyun bu sorulara şu şekilde bir yanıt vermişti: Birinci konuda Taşnaksutyun Osmanlı İmparatorluğu’nun egemenliğini savunacaktı. Dr. Bahaeddin Şakir ve Ömer Naci bu yanıtı duymaktan ziyadesiyle memnun olmuştu. ${ }^{78}$ İkinci soruya yanıtta ise bu konuda daha fazla bilgilenmeye ihtiyacı olduklarını ve konuyu tartışmanın zamanı olmadığı yanıtını vermişlerdi.

Kaligian'ın tespitlerine göre; Dr. Bahaeddin Şakir ve Naci Bey, birinci teklifi yaparken Kafkas Müslümanlarının kendilerine yardım edeceğinden emin olduklarını da belirtmişlerdi. İkinci konuda beklentileri ise, Taşnaklar'ın Kafkas Ermenileri üzerinde nüfuzu olduğuna ve onları Osmanlı kuvvetlerine destek vermeye

75 Vratzian, Hayasdani Hanrabedutiune, s. 9. Vratsian, Armenia and the Armenian Question, s. 25.

76 Papazian, "Hamashkharhayin Baderazmuh", s. 3-9.

77 Tetik, Teşkilat-ı Mahsusa, s. 271.

78 Yılmaztürk’ün kaydettiğine göre Terzipashian da İttihatçı heyetin bu cevaptan memnun kaldığını yazar. Türkyılmaz, "Rethinking Genocide”, s. 165. 
ikna edebilecekleri bilgisine dayanmaktaydı. Ayrıca Papazian’a göre Taşnaklar, Rusya Ermenileri adına konuşma veya karar verme yetkileri olmadığını Bahaeddin Şakir'e açıkça iletmişlerdi. Üstelik Osmanlı Devleti'nin "Batı Ermenistan”da son yıllarda verdiği sözleri tutmamış olması, Rusya Ermenilerini Taşnakların ikna etmesinin önünde engeldi. ${ }^{79}$

Esasen perde gerisinde konuşulanlara göre Ermeniler, reformları sürekli savsaklayan İttihat ve Terakki Partisi yüzünden Osmanlı devletine sadık kalma konusunda bile Ermeni halkını ikna edebileceklerinden emin değildi. Bu diyalog gerçekten ilginç ve iddialı vaatler içermektedir, ancak bunları doğrulamak mümkün görünmüyor. Zira Kaligian'ın kullandığı Boston'daki Taşnaksutyun arşivine bugüne kadar sadece birkaç araştırmacı girebilmiştir. Ancak Vratsian’ın anılarında da benzer cümleler vardır. İlave olarak, Vratsian İttihatçı heyetin kendilerine "Osmanl sınırlar içindeki Ermeni vilayetleri" yanında Rusya topraklarını da kapsayacak şekilde özerk bir Ermenistan kurmayı vaat ettiklerini, teklifi geri çevirdikleri takdirde Ermenilerin sonuçlarına katlanacaklarını belirttiklerini de iddia etmektedir. ${ }^{80}$ Ayrıca anılarında Erzurum Kongresinden bahseden Vahan Papazian da İttihatçıların Kafkaslar’a hâkim olmayı planladıklarını, Taşnakların savaşta tarafsı kalma ve kendilerini desteklememe kararından ise memnun kalmadıklarını öne sürmektedir. Ona göre İttihatçılar, Erzurum Kongresinde Taşnakların aldığı kararı da öğrenmişler ve sonuçlarına katlanacakları şeklinde bir tehditte bulunmuşlardır. ${ }^{81}$ Tarık Zafer Tunaya da İttihatçıların önerilerinin özerk bir Ermenistan kurulması yönünde olduğunu belirtir. ${ }^{82}$

Hâlbuki bu iddialara karşılık, Dr. Bahaeddin Şakir ve Teşkilat-ı Mahsusa’nın Doğudaki görevlilerine gönderilen görev emirleri arasında, özellikle Ermenilerin kazanılması veya taraf olmaları için pazarlık yapılmasından söz edilmemektedir. Teşkilat-1 Mahsusa'ya verilen görev, "Rusya havalisinde Ruslar aleyhine başlayan ihtilâli tevsi etmek ve Rus kıtaatının bütün Acemistan havalisinden def'ini temin eylemek, harekât-1 âtiye için gayr-i kâbil-i ihmâl ve imhâl bir başlangıç"83 olacağı yönündedir. Esasen, Ekim 1914 başlarında bile Osmanlı Devleti'nin bölgedeki yetkililerinde Ermenilerin ihanetine dair bir kanaat oluşmamış olduğu

79 Papazian, "Hamashkharhayin Baderazmuh", s. 3-9.

80 Vratzian, Hayasdani Hanrabedutiune, s. 9.

81 Papazian, "Hamashkharhayin Baderazmuh", s. 3-9.

82 Tunaya, Ittihat ve Terakki Cemiyeti, s. 649.

83 Tetik, Teşkilat-ı Mahsusa, s. 280. 
anlaşılmaktadır. Çünkü, Binbaşı Süleyman Askeri bu tarihlerde Dr. Bahaeddin Şakir ve Rıza Bey, "Ermeniler bizimle teşrik-i mesai etmeseler bile, bî-taraflıklarını istihsale çalışmak ve bu veçhile mecburiyet-i kat' 'iye olmadan inkisâr-1 kalplerine meydan vermemek lüzumu hakkında icâb edenlerin nazar-1 dikkatini celb ediniz" demektedir. $^{84}$

Buna karşılık tarihçi Michael Reynolds görüşmelere dair kayıtların sadece Ermeni hatıralarından ibaret olduğunu zannederek şu şekilde bir yorum getiriyor: Osmanlı Devleti'nin zaferle çıktığı bir savaştan sonra Ermenilere bazı Doğu vilayetlerinin kontrol ve yönetimini verdiğini düşünmek çok zordur. Reynolds’a göre mantıklı açıklama şu olabilir: Osmanlı hükümeti senaryo gereği Taşnaklara kabul etmeyeceklerini bildikleri bir teklif yapmışlardır. Taşnaklar kibarca reddecek ve kerhen devlete sadık kalacaklarını bildireceklerdi. Zira Osmanlı Devleti'nin Ermenilere ittifak teklif etmesi, onları zaten müttefik olarak görmediği anlamına da gelir. ${ }^{85}$ Ayrıca Vratsian'a göre Osmanlı hükümeti savaşa girme kararını çoktan vermişti. ${ }^{86}$ Papazian da bu fikirdedir. ${ }^{87}$ Hatta Osmanlılar Almanya'nın askeri üstünlüğüne ve savaşın galibi olacağına inandıklarını ifade etmişlerdi. Nitekim Dr. Bahaeddin Şakir de Ermeni delegelerine Almanya ve İttifak devletlerinin gücü ve yenilmezliği hakkında bir nutuk çekmiş, Osmanlı devletinin Hilafet avantajını kullanarak İtilaf devletlerini sömürgelerde zor duruma düşüreceğini kaydetmiştir. $^{88} \mathrm{Bu}$ yüzden Taşnaklar sadece Osmanlı İmparatorluğu içinde değil, davalarına inançlarından dolayı, Kafkasyảda da kendileriyle işbirliği yapmalıydı. Bu tarihi fırsat bir daha gelmezdi. Bu yüzden İttihatçı heyet, Taşnaklara cephe gerisinde Osmanlı ordusuna yardımcı olması ve Rusya’nın savaş gücünü zayıflatması için Diaspora ve Kafkasya Ermenilerinden gönüllü birlikler oluşturmasını önermişti.

İttihatçıların Ermenilerden beklentilerine dair Yektan Yılmaztürk'ün naklettiği kaynak ise bu konuda daha fazla bilgi içermektedir. Taşnak arşivlerindeki bir belgeye göre, İttihatçı heyet Taşnaklardan, Kafkasya ve İran'daki Ermeniler arasında Osmanlı hükümeti için propaganda yapacak bir grup oluşturmaktaydı. Bu

84 Tetik, Teşkilat-ı Mahsusa, s. 291.

85 Michael Reynolds, "The Ottoman-Russian Struggle for Eastern Anatolia and the Caucasus, 1908-1918, Identity, Ideology and the Geopolitics of World Order" (Ph. D. Dissertation), Princeton University, 2003, s. 372-73.

86 Vratzian, Hayasdani Hanrabedutiune, s. 9'dan nakleden Türkyılmaz, "Rethinking Genocide", s. 163.

87 Papazian, "Hamashkharhayin Baderazmuh", s. 3-9.

88 Önol, "The Eight World Congress", s. 788. 
propagandaların amacı, olası bir Osmanlı-Rusya savaşında Rusya ordusuna karşı savaşacak "gönüllü" bir birlik oluşturmaktı. Bu gönüllü birlikler, Kafkasya'da Rusya’ya karşı isyan başlatacaklardı. İttihatç̧ların bu planı uygulamasının zor olmayacağını, çünkü Gürcü, Türk, Azeri ve diğer Müslüman Kafkasyalıların zaten isyana hazır olduklarını iddia ediyordu. Ermenilerin yapması gereken isyancılara katılmaktan ibaretti. Bu kaynağa göre Gürcülere bu hizmetleri karşıllı̆ıında Tiflis ve Kutaisi Vilayetlerini içine alan ve Trabzon vilayetinin doğu sınırlarına kadar uzanan özerk bir bölge vaat edilmişti. Aynı şekilde Azerilere de bir bölgede özerklik sözü verilmişti. Hatta İttihatçılar, ceplerinden çıkarttıkları bir harita üzerinde bu bölgeleri Ermenilere göstermişti. ${ }^{89}$ Ruben Ter Minassian'ın hatıratında vaat edilen özerk ve birleşik bir Ermenistan'ın merkezinin Eçmiyadzin olduğu bilgisi de yer alıyor. Bununla birlikte yine Ter Minassian, Taşnakların iki özerk Ermenistan bölgesi isteğini de not ediyor. Taşnaksutyun'un planı Kafkasya’da Rusya himayesinde bir fedarasyon, Osmanlı sınırları içerisinde özerk bir Ermenistan idi. ${ }^{90}$ Pastırmacıyan da özerklik teklifinin tartışılmaz olduğunu ve Ermeni kongresine, Türk hükümeti adına şu önerinin sunulduğunu iddia etmektedir:" ${ }^{91}$

"Eğer Türk ve Rus Ermenileri hep birlikte, aktif olarak Türk ordularını desteklerlerse, Türk Hükümeti Alman garantisi altında savaş bitiminde (Rus Ermenistan’ı ve üç Türk vilayeti Erzurum, Van ve Bitlis’ten müteşekkil bölgede) Ermenilere, Osmanlı yönetimi altında özerklik vermeyi taahhüt eder." ${ }^{2}$

Bunların dışında bir başka önerileri de Taşnakların diaspora Ermenilerini Osmanlı-Ermeni dayanışması konusunda cesaretlendirmeleri ve Ermeni sorununa müdahil olan bütün dış güçlerle ilişkilerini koparmalarıydı. Ancak bu şekilde savaşın sonunda Ermeni sorununa kesin bir çözüm bulunabilirdi. Vramian, bu taleplere bir soru ile yanıt verdi. Ermenilerin Türklere teklifi ne olabilir? Yine Vramian'ın iddiasına göre bu soruya heyetteki hiç kimse cevap verememişti. Çünkü Ermenilerin İttihatçların teklifini kabul etmesi, Kafkasya'ya belirsizlik getirecek ve Ermenileri maceraya sokacaktı. İttihatçıların teklifi, ne Ermeni özgürlük mücadelesinin amaçlarına ne de Ermenilerin milli emelleriyle örtüşüyordu.

89 Türkyılmaz, "Rethinking Genocide”, s. 160. Krş. Önol, “The Eight World Congress”, s. 786.

90 Minassian, Hay Heghapokhagani, s. 126-27. Bu eserin ilgili kısımlarını benim için tercüme eden Ercan Cihan Ulupınar'a müteşekkirim.

91 Pastermadjian, Why Armenia Should be Free, s. 26.

92 Pastermadjian, Why Armenia Should be Free, s. 27. 
Ancak, Dr. Bahaeddin Şakir'in teklifini geri çevirmek düşmanlık olarak algılanabilir ve bunun Batı Ermenilerine bedeli çok ağır olabilirdi. Vramian’a göre İttihatçılar, "Ermeniler, Osmanlı devletine olan vatandaşlık görevlerini yerine getireceklerdir" şeklindeki Erzurum Taşnak Kongresinde alınan kararı yetersiz görüyor, Ermenilerin askeri birlikler oluşturarak Rusya'ya karşı savaşmasını ve hatta Osmanlı ordusunun önünde Erzurum'dan Kars’a yürümesini bekliyorlardı. ${ }^{93}$

Vramian'a atfen yazılanlara göre görüşmelerden bir sonuç çıkmamıştır. Buna rağmen iddialara göre Taşnaklar devlete bağlılıklarını korumak konusunda kararlılıklarını korumuşlardı. Kongre sırasında İttihatçılarla görüşen Ermeni temsil heyeti, Osmanlı hükümeti ve tabii ki iktidarla köprülerin atılmasının sakıncalarını görmüş olmalıdır. Ermeni delegelerin büyük bir çoğunluğu savaşın Doğu Anadolu’daki etnik çatışmaları körükleyeceğinden korkmaktaydı. Ayrıca savaşı Almanya ve müttefiklerinin kaybedeceğinden de emindiler. Bu yüzden partinin, Ermenilerin güvenliğini sağlamasını ve bu amaçla önlemler almasını istiyorlardı. Bu endişe ile bazı Taşnaklar, sadakatin ve devlete bağlılığın cephenin her iki tarafındaki Ermeniler için de tartışılmaz şekilde en iyi yol olduğunu düşünmekteydiler. Bu durum, Rusya Ermenileri ile Osmanlı Ermenilerini karşı karşıya getirecek ve "kardeş kardeşe karşı" bir savaş doğuracak olsa da ihanet içinde olunmamalıydı. Bu tartışma ve görüşleri bize aktaran Vahan Minorkian’ı doğrulamak mümkün olmasa da, Erzurum’daki Taşnak kongresinde Osmanlıya sadık kalma görüşünde olanların samimiyetle radikallere karşı mücadele ettiğini ortaya koyduğunu kabul etmek gerekir ${ }^{94}$

Erzurum'daki görüşmeler hakkında bilgi veren bir diğer Ermeni kaynağı ise Hratch Dasnabediandır. Üstelik o, Minorkian’ın yazdıklarını tartışmaya açacak çok farklı bilgiler vermektedir. ${ }^{95}$ Hratch Dasnabedian'ın hatıratında naklettiğine göre, Rusya’nın cesaretlendirmesi söz konusu idi fakat Ermeni Milli Bürosu

93 Taşnak-İttihatçı buluşması veya görüşmelerinin detayları hakkında atıf yaptığımız hatırat ve kaynaklara ek olarak şu makaleye de başvurulabilir: Rober Koptaş, "Zohrab, Papazyan ve Pastırmacıyan'ın kalemlerinden 1914 Ermeni reformu ile İttihatçı-Taşnak müzakereleri”, Tarih ve Toplum, 5 (2007), s. 159-178.

94 Türkyılmaz, "Rethinking Genocide”, s. 158. Benzeri tartışmalar yaşandığı hakkında bkz. See Gerard Chaliand ve Yves Ternon, The Armenians: From Genocide to Resistance, çev. Tony Berrett, (London: Zed Press, 1983), s. 195-96.

95 Hratch Dasnabedian, Ho.Hee.Tashna.g.tsutyan Gazmagerbagan Garuytsee Holovuyte Yev Ayl Usumnasirutyunner (History of the Organizational Structure of the Armenian Revolutionary Federation and Other Studies), ed. Yervant Pampukian, (Beirut: Hamazkayin Vahe Setian Press, 2009), s. 375. 
kararıyla Kafkasya Cephesinde Ermeni Gönüllü Birlikleri zaten oluşturulmuştu. Taşnaksutyun, bu plana Kafkas Bölgesi Kongresinden ${ }^{96}$ sonra, 1914 yılının Eylül ayında dâhil olmuştu. Nitekim Rus arşiv belgeleri Ermeni Gönüllü Birliklerinin Erzurum'da kongre toplanmadan önce oluşturulmaya başlandığını, kongreden hemen sonra da hız kazandığını göstermektedir. Örneğin,1 Ağustos 1914 tarihli bir istihbarat raporuna göre, Tiflis’te Taşnak mensubu öğretmen ve öğrencilerin yaptığı kongrede Osmanlı Ermenilerinin Türklere karşı ayaklanmalarını desteklemek amacıyla silah alımı için para toplanmasına karar verildiği ifade edilmektedir. ${ }^{97}$ Bir başka belgede, Ağustos itibariyle Taşnakların tüm enerjilerini Türkiye’ye karşı ayaklanmak üzere teksif ettikleri belirtilmektedir. ${ }^{8} 29$ Ağustos 1914 tarihli bir rapora göre ise, Türk ordusundaki Ermenilerin Rusya tarafına geçmeye başladıkları ve buna teşvik edildikleri anlatılmaktadır. ${ }^{99}$

$\mathrm{Bu}$ satırlardan anlaşılan şudur: Erzurum'daki kongrede alındığı iddia edilen karara göre, Osmanlı Ermenilerinin, Osmanlı Devleti savaşa girdiği takdirde devlete sadık kalacaklarına dair Erzurum kongresinde alındığı iddia edilen karar tabanda taraftar bulmamış, radikal Taşnaklar Rusya safına katılmak için çalışmalarını yoğunlaştırmıştır. Nihayet Tiflis'te toplanan Kafkasya Bölgesi Kongresi'nde Ermenilerin silahlanması, Rusya ordularına katılması ve 'gönüllü' birliklerdeki Ermeni asker sayısının artırılması kararı alınmıştır. ITC’nin özerklik teklifi de yetersiz bulunmuş ve kabul görmemiştir. Bu tarihten sonra Taşnaklar, açıkça Rusyảnın yanında savaşa girme kararı almışlardır. Nitekim Minorkian da bazı Ermenilerin Osmanlı topraklarında henüz Osmanlı Devleti dünya savaşına dâhil olmadan önce isyan hazırlıkları yaptıklarını yazmaktadır. Özellikle Andranik, Hamazasp ve Tigran Khachikian isyan bayrağının bir an önce açılması için Tiflis'te yoğun bir şekilde faaliyet yürütmüş, bu yönde karar alınmasını kongreye teklif etmişlerdi. ${ }^{100}$ Hamazasp da zaten çetesini çoktan faaliyete geçirmiş ve bazı eylemleri 1914 yılı Eylül ayında ses getirmeye başlamıştı. Daha önemlisi

96 Taşnaksutyun Kafkasya Bölge Kongresi 1914 yılının Eylül ayında, yani Erzurum Kongresinden sonra toplanmıştır.

97 Belge No. 12: GARF. Fon 102. Sayı. 244 (1914). Dosya 14. Bölüm 79 LB. Sayfa 54 arkası. Aktaran Chernichenkına, Rus Imparatorluk Kayıtlarında Ermeni Sorunu 1912-1917, s. 115.

98 Belge 13: GARF. Fon 102. Sayı 244 (1914). Dosya 14. Bölüm 92 LB. Sayfa 53-53 arkası. Aktaran, Chernichenkına, Rus Imparatorluk Kayıtlarında Ermeni Sorunu 1912-1917, s. 116.

99 Belge No. 14. GARF. Fon 102. Sayı. 244 (1914). Dosya 14. Bölüm 79 LB. Sayfa 55 arkası, 56. Chernichenkına, Rus Imparatorluk Kayıtlarında Ermeni Sorunu 1912-1917, s.117-18. 100 Türkyılmaz, "Rethinking Genocide”, s. 159. 
Andranik tarihleri doğru hatırlıyorsa, kendisine Taşnak Partisi Batı Bürosu (İstanbul) tarafından Ağustos ayında Tiflis'e gitmesi emri verilmişti. 2 Ağustos'ta Tiflis'e varan Andranik, orada Taşnak sözcüsü Dr. Hakob Zavriev ile buluşmuş ve sözcü Zavriev tarafından Rusya’nın Kafkas Orduları komutanına götürülmüştü. Andranik, Rus ordusuna rehberlik yapma emri almıştı. ${ }^{101}$ Başka bir deyişle Türk tezine yakın tarihçiler kongrede alınan veya deklare edilen tarafsızlık kararının bir taktik olduğunu, gerçekte Rusya ile ittifak kararı alındığını iddia etmektedir. ${ }^{102}$ Bu bilgi doğru ise, Erzurum'daki kongrede radikal kanadın görüşlerinin hayata geçirildiği ve böylece Ermenilerin ihanetinin kesinliği de anlaşılmaktadır.

\section{Sonuç}

$\mathrm{Bu}$ makalemizde, Taşnakların 1914 yılının Temmuz-Ağustos aylarında Erzurum'da topladıkları VIII. Kongre ve bu kongrede alınan kararlar tartışılmıştır. Tarafların farklı beyanlarda bulunmalarına rağmen, Erzurum'daki kongreye İttihatçıların da bir aşamadan sonra katıldıkları anlaşılmış ve sadece kongreye katılmak için görevlendirilmemiş olsalar bile, İttihatçı heyetin önde gelen Ermeni delegelerle görüşmeler yaptığı tespit edilmiştir. Bu görüşmeler sonucu Taşnak Kongresi, Osmanlı Devleti’ne sadık kalacağı ve vatandaş olarak görevlerini yerine getireceğine dair politik bir karar almıştır. Bu karar, Patrik Zaven’in görüşlerine paraleldir. Öte yandan Osmanlı delegasyonu, muhtemelen Ermenilere özerklik veya yeni bir statü de teklif etmiştir. Rusya Ermenilerinin Osmanlı tarafına geçmeye ikna edilmesi karşıllı̆̆ında, bu tavizin verilmesi anlaşılabilirdi. Ne var ki bu teklif bile Taşnaklar tarafından reddedilmiştir. Belli ki Taşnaklar, İttihatçılara hiç güvenmiyordu. Yeniköy İtilafnamesinin hayata geçirilmesi konusunda İttihatçların ayak sürümesini bu kararlarına dayanak yapıyorlardı. Öte yandan ITC de Taşnakların niyetlerini önceden biliyordu. Yine de Dr. Bahaeddin Şakir kongreye gönderilerek Taşnakların gerçek niyetleri hakkında olabildiğince bilgi elde etme yolu seçilmişti. Burada bazı yazarların, Dr. Baheddin Şakir'in gerçek niyetinin kongrenin toplanmasını engellemek ve delegeleri yok etmek olduğu şeklindeki komplo teorilerini asılsız bir iddianın tekrarı olarak gördügüumüzü belirtelim. Osmanlı Devleti, Ermenilere yaptığı teklifin reddedilmesine rağmen, Ermeni vatandaşlarının tarafsızlığının ve güvenliklerinin sağlanmasını daima öncelikleri arasında saymıştır. ${ }^{103}$

101 Chalabian, General Andranik, s. 218.

102 McCarthy v.dğr., The Armenian Rebellion at Van, s. 182; İlter, Türkiye'de Sosyalist, s. 53-54.

103 Önol, “The Eight World Congress”, s. 789. Önol burada bu görüşün ciddiyetten uzak olduğuna dair kanıtları sıralamaktadır. 
Kongre sonrası gelişmeler ise daha ilginçtir. Her ne kadar İTC ile Taşnaklar arasında kongre sonrasında görüşmeler İstanbul'da sürse de Ermeniler Rusya'ya daha yakın durmuşlardır. Resmi görüşmelerde tarafsızlıklarını koruduklarını beyan etseler de gizliden gizliye tıpkı Rus topraklarındaki soydaşları gibi, gönüllü birlikler kurmaya ve silahlanmaya devam ermişlerdir. Diaspora Ermenileri de gönüllü toplamaya ve cepheye göndermeye başlamışlardır. Kasım ayında ise Tiflis’te toplanan Kafkas Kongresinde, Taşnak Partisi Rusya ile müttefik olarak Osmanlı Devleti ile savaşma kararı almıştır. ${ }^{104} \mathrm{Bu}$ konu hakkındaki farklı görüşlerin ortaya çıkmasının sebebinin, aynı yıl iki farklı kongre yapıldığının göz ardı edilmesi olduğu anlaşılmaktadır. Tiflis Kongresi bu bakımdan ayrıntılı bir şekilde tartışılmalıdır, ancak bu makalenin kapsamı dışındadır.

Bu ikinci kongrede alınan karar göz önüne alındığında, Ermenilerin henüz Osmanlı Devleti, Dünya savaşına dâhil olmadan kararlarını vermiş oldukları ve İtilaf devletlerine meylettikleri anlaşılacaktır. Bu nedenle, Yılmaztürk'ün Erzurum Kongresi'nin "bir sonun başlangıcı"105 olmadığı şeklindeki görüşüne katılmakla birlikte, Tiflis'te yapılan genel kongrenin İttihat Terakki Partisi ile Osmanlı Ermenileri arasındaki ilişkilerin seyrini belirleyen bir toplantı olduğunu belirtmek gerekir. Zira bu toplantıda Taşnaklar arasında farklı fikirlerin değerlendirildiği ve Erzurum Kongresinde alınamayan bazı önemli kararların burada alındığı anlaşılmaktadır. Bu çerçevede Dasnabedian'ın belirttiğine göre, Ermeni "gönüllü” birliklerinin oluşturulmasına ve Ermeni Milli Kongresi'nin toplanmasına karar verilmiştir. ${ }^{106} \mathrm{Bu}$ durum, açıkça Osmanlı Devletine karşı bir savaş ilanı anlamına gelmektedir. Bu bilgiler ışığında İttihatçıların hiçbir şekilde Taşnak kongresine katılmadıkları, müzakere yapmadıkları ve dolayısıyla özerklik gibi yeni statü tekliflerinin doğru olmadığını savunmak mümkün değildir. Yeni hatırat ve belgeler bu savın savunulmasını zorlaşıırmışıır.

104 Tiflis Kongresi için bkz. Türkyılmaz, "Rethinking Genocide”, s. 178.

105 Türky1lmaz, "Rethinking Genocide", s. 166. "Clearly, the Erzurum meeting did not mark the beginning of the end".

106 Dasnabedian, The History of the Armenian Revolutionary Federation, s. 109. 
KEMAL ÇİÇEK

VIII. Taşnak Kongresinin Perde Arkası ya da Taşnakların I. Dünya Savaşı Öncesi Müttefik Arayışı

Öz - Osmanlı Ermenileri içinde ciddi bir grup isyancıları desteklemiş, I. Dünya Savaşı'nda ülkelerine ihanet etmiş ve Rusya saflarında savaşmışlardır. Ermeni tarih yazıcılığı ise Osmanlı Ermenilerinin devletlerine sadık kaldıklarını ve bu kararın 1914 yılı Ağustos ayında Erzurum'da toplanan VIII. Taşnak Kongresi'nde karara bağlandığını ileri sürmektedir. Ermeni soykırım tezini savunan tarihçiler, Taşnak kongresine Osmanlı hükümetini temsilen bir heyet gönderildiğini ve bu heyetle yapılan görüşmelerde Ermenilere Osmanlı Devleti'nin stratejik hedefleri doğrultusunda savaşa katıldıkları takdirde özerklik vaat edildiğini ileri sürmektedir. Tarihçi Esat Uras'ın önderlik ettiği ve soykırım tezlerini reddeden bir grup tarihçi ise Osmanlı hükümetini veya İttihat ve Terakki Partisini temsilen Erzurum'a bir heyet gittiğini kesinlikle kabul etmemekte ve bu iddianın Ermeniler tarafından savaş sonrasında özerklik taleplerini güçlendirmek amacıyla ortaya atıldığını ileri sürmektedir. Bu makalede yeni ortaya çıkan hatırat, arşiv belgeleri ve araştırmalar ışığında üç soruya yanıt aranmaktadır. 1) VIII. Taşnak Kongresi'ne Osmanlı hükümetini temsilen bir katılım olmuş mudur? 2) Kongrede özerklik veya Osmanlı ordusuyla işbirliği yapma karşılığında Ermenilere herhangi bir vaatte bulunulmuş mudur? 3) Tarih yazımında Taşnak kongresi ve perde arkası hakkında birbirine tamamen zıt görüşler ortaya atılmasının sebepleri neler olabilir? Bu makalede, karşıt görüşlerin bir değerlendirmesini yapılarak, Taşnak Kongresi'nin perde arkasında yaşananlar, belgeler ışığında açıklığa kavuşturulmaktadır. Sonuç olarak Osmanlı Hükümeti ile Taşnak Partisi arasında görüşme olmadığına dair tezlerin savunulabilir olmadığı ortaya konulmaktadır.

Anahtar kelimeler: Osmanlı Devleti, Ermeni Sorunu, VIII. Taşnak Kongresi, İttihat ve Terakki Cemiyeti (ITC).

\section{Kaynaklar}

Akçam, Taner: İnsan Hakları ve Ermeni Sorunu, Ankara: İmge Kitabevi 2002.

Aksakal, Mustafa: The Ottoman Road to War in 1914: The Ottoman Empire and the First World War, New York: Cambridge University Press 2008.

Bobelian, Michael: Children of Armenia: A Forgotten Genocide and the Century-long Struggle for Justice, New York: Simon and Schuster 2009.

Chalabian, Antranig: General Andranik and the Armenian Revolutionary Movement, Melrose: [yayl.y.] 1988.

Chaliand, Gerardv ve Yves Ternon: The Armenians: From Genocide to Resistance, çev. Tony Berrett, London: Zed Press 1983.

Chernichenkina, Natalia: Rus Imparatorluk Kayıtlarında Ermeni Sorunu 1912-1917, Erzurum: Erzincan Üniversitesi Yayınları 2015. 
Corrigan, H. S. W.: "German-Turkish Relations and the Outbreak of War in 1914: A Re-assessment", Past \& Present, 36 (1967), s. 144-152.

Çiçek, Hikmet: Dr. Bahattin Şakir: İttihat ve Terakki'den Teşkilatı Mahsusảya Bir Türk Jakobeni, 2. Baskı, İstanbul: Kaynak Yayınları 2007.

Çiçek, Kemal: "VIII. Taşnak Kongresi: Ermenilerin Karar Anı", I. Uluslararası TürkErmeni İlişkileri ve Büyük Gǚller Sempozyumu (2-4 Mayıs 2012-Erzurum/Türkiye), Erzurum: Atatürk Üniversitesi Türk-Ermeni İlişkileri Araştırma Merkezi Yayınları 2014, s. 63-72.

Dasnabedian, Hratch: The History of the Armenian Revolutionary Federation Dashnaktsutiun (1890-1924), Milan: Oemme Edizioni 1989.

Dasnabedian, Hratch: Ho. Hee.Tashna.g.tsutyan Gazmagerbagan Garuytsee Holovuyte Yev Ayl Usumnasirutyunner [History of the Organizational Structure of the Armenian Revolutionary Federation and Other Studies], ed. Yervant Pampukian, Beirut: Hamazkayin Vahe Setian Press 2009.

Documents on Ottoman Armenians, I-III, Ankara: Prime Ministry Directorate General of Press and Information 1982.

Erickson, Edward J.: Ottomans and Armenians: A Study in Counterinsurgency, New York: Palgrave Macmillan 2013.

Ermeni Komitelerinin Amâl ve Harekât-ı İhtilaliyesi: İlan-ı Meşrutiyet'den Evvel ve Sonra, İstanbul: Matbaa-i Amire [1332] 1916.

Gürün, Kamuran: Ermeni Dosyası, 2. Baskı, Ankara: Türk Tarih Kurumu 1983.

Hanioğlu, M. Şükrü: A Brief History of the Late Ottoman Empire, Princeton, NJ: Princeton University Press 2008.

Hovannisian, Richard G.: "The Armenian Question in the Ottoman Empire, 18761914", The Armenian People from Ancient to Modern Times, ed. Richard G. Hovannisian, II, New York: St. Martin’s Press 2004.

Hovannisian, Richard G.: Armenian Van/Vaspurakan, Los Angeles: UCLA 2000.

Hovannisian, Richard G.: The Armenian People from Ancient to Modern Times, II: Foreign Dominion to Statehood: The Fifteenth Century to the Twentieth Century, New York: St. Martin's Press 1997.

Hovannisian, Richard G.: "Simon Vratzian and Armenian Nationalism", Middle Eastern Studies, V/3 (1969), s. 192-220.

İlter, Erdal: “Ermenilerin Tehciri ve Türkler’ in Göçü (1915-1918)”, Ermeni Araştırmaları, 9 (2003), s. 30-40.

İlter, Erdal: Türkiye'de Sosyalist Ermeniler'in Silablanma Faaliyetleri ve Milli Mücadeléde Ermeniler 1890-1923, Ankara: Turhan Kitabevi 2005. 
Kaligian, Dikran: Armenian Organization and Ideology Under Ottoman Rule: 1908-1914, 2. Bask1, London: New Brunswick, N. J: Transaction Publishers 2011.

Kaligian, Dikran: "Anatomy of Denial: Manipulating Sources and Manufacturing a Rebellion," Genocide Studies International, 8/2 (2014), s. 208-223.

Kevorkian, Andre: The Armenian Genocide: A Complete History, London: I. B. Tauris 2011.

Khudaverdyan, K. Acad (ed.): The Armenian Question: Encyclopedia, Erivan 1996.

Koptaş, Rober: “Zohrab, Papazyan ve Pastırmacıyan'ın Kalemlerinden 1914 Ermeni Reformu ile İttihatç1-Taşnak Müzakereleri”, Tarih ve Toplum, 5 (2007), s. 159-178.

Lewy, Guenter: The Armenian Massacres in Ottoman Turkey: A Disputed Genocide, Salt Lake City: The University of Utah Press 2005.

McCarthy, Justin v.dğr.: The Armenian Rebellion at Van, Salt Lake City: The University of Utah Press 2006.

McMeekin, Sean: The Russian Origins of the First World War, Cambridge, Mass./London: The Belknap Press of Harward University Press 2011.

Minakhorian, Vahan: 1915 Tvakane [The Year 1915/1915 Yil1], Venice: St. Ghazar Press 1949.

Minassian, Gaidz F. ve Arsen Avagyan: Ermeniler ve İttihat ve Terakki İ̧birliğinden Çatışmaya, çev. Ludmilla Denisenko, Mutlucan Şahan, yay. haz. Rober Koptaş, İstanbul: Aras 2005.

Minassian, Ruben Ter: Hay Heghapokhagani Me Hishadagnere, VII, 3. Baskı, Tehran 1982.

Osmanlı Belgelerinde Ermeni-Rus İlişkileri, Ankara: Devlet Arşivleri Genel Müdürlüğü 2006.

Öke, Mim Kemal: The Armenian Question, Ankara: Türk Tarih Kurumu 2001.

Önol, Onur: "The Eight World Congress of the Dashnaktsutyun and Its Aftermath", War and Collapse, ed. Hakan Yavuz ve Feroz Ahmad, Salk Lake City: Utah University Press 2016, s. 781-799.

Papazian, Vahan: "Hamashkharhayin Baderazmuh yev Daroni Ashkharhuh," [The World War and the Region of Daron/I. Dünya Savaşı ve Daron Bölgesi] Vem, 3:3 (Jul.Aug., 1935), s. 3-9.

Pastermadjian, Karekin: Why Armenia Should be Free, Boston: Hairenik Publishing Company 1918.

Price, Clair: The Rebirth of Turkey, New York: Thomas Seltzer 1923.

Reynolds, Michael: The Ottoman-Russian Struggle for Eastern Anatolia and the Caucasus, 1908-1918, Identity, Ideology and the Geopolitics of World Order, (Doctoral Dissertaion) Princeton University, 2003. 
Sonyel, Salahi R.: The Turco-Armenian Imbroglio: Prospects for Reconciliation, London: Cyprus Turkish Association 2005.

Ternon, Yves: Bir Soykırmm Taribi (20 Yıl Sonra Ermeni Tabusu Davasi), İstanbul: Belge Yayınları 2000.

Tetik, Ahmet: Teşkilat-ı Mabsusa (Umur-ı Şarkıyye Dairesi) Tarihi, I, İstanbul: Türkiye İş Bankası Yayınları 2014.

Toynbee, Arnold J. ve James Bryce: The Treatment of Armenians in the Ottoman Empire: Documents Presented to Viscount Grey of Fallodon, Secretary of State for Foreign Affairs, London: Hodder \& Stoughton 1916.

Trumpener, Ulrich: "German Military Aid to Turkey in 1914: An Historical Reevaluation", The Journal of Modern History, 32/2 (1960), s. 145-149.

Tunaya, Tarık Zafer: Türkiye'de Siyasi Partiler, c. 3: İttihat ve Terakki: Bir Çağın, Bir Kuşağın, Bir Partinin Taribi, 3. Baskı, İstanbul: İletişim Yayınları 2007.

Türközü, Halil Kemâl: “Taşnak Partisinin 8'inci Kongresi”, Belgelerle Türk Taribi Dergisi, Dün/Bugün/Yarın, 12 (1986), s. 68-73.

Türkyılmaz, Yektan: Rethinking Genocide: Violence and Victimhood in Eastern Anatolia, 1913-1915 (Doctoral Dissertaion), Duke University, 2011.

Uca, Alaattin: İttihad ve Terakki Liderlerinden Doktor Bahaeddin Şakir Bey, (Doktora Tezi) Erzurum: Atatürk Üniversitesi, 2009.

Uras, Esat: Taribte Ermeniler ve Ermeni Meselesi, Ankara: Türkiye Matbaacılık ve Gazetecilik 1950.

Ussher, Clarence D.: An American Physician in Turkey: A Narrative of Adventures in Peace \& War, Boston, MA: Houghton Mifflin Company 1917.

Vratsian, Simon: Armenia and the Armenian Question, çev. James G. Mandalian, Boston: Hairenik Publishing Company 1943.

Vratzian, Simon: Hayasdani Hanrabedutiune [The Republic of Armenia/Ermenistan Cumhuriyeti], Paris 1928.

Yeghiayan, Zaven Der: My Patriarchal Memoirs, çev. Ared Misırliyan, haz. Vatche Ghazarian, Barrington: Mayreni Publ. 2002.

Yılmaz, Veli: "I’inci Dünya Harbi ve 2 Ağustos 1914 Tarihli Türk Alman İttifak Antlaşması", Ankara Üniversitesi Türk İnkılâp Tarihi Enstitüsü Atatürk Yolu Dergisi, 11 (1993), s. 121-31. 